\title{
Genome characteristics reveal the impact of lichenization on lichen-forming fungus Endocarpon pusillum Hedwig (Verrucariales, Ascomycota)
}

Yan-Yan Wang ${ }^{1,2+}$, Bin Liu ${ }^{3+}$, Xin-Yu Zhang ${ }^{1 \dagger}$, Qi-Ming Zhou ${ }^{1 \dagger}$, Tao Zhang ${ }^{1,2}$, Hui Li ${ }^{1,2}$, Yu-Fei Yu ${ }^{1}$, Xiao-Ling Zhang ${ }^{1}$, Xi-Yan $\mathrm{Hao}^{3}$, Meng Wang ${ }^{3}$, Lei Wang ${ }^{3^{*}}$ and Jiang-Chun Wei ${ }^{i^{*}}$

\begin{abstract}
Background: Lichen is a classic mutualistic organism and the lichenization is one of the fungal symbioses. The lichen-forming fungus Endocarpon pusillum is living in symbiosis with the green alga Diplosphaera chodatii Bialsuknia as a lichen in the arid regions.

Results: 454 and Illumina technologies were used to sequence the genome of E. pusillum. A total of 9,285 genes were annotated in the $37.5 \mathrm{Mb}$ genome of E. pusillum. Analyses of the genes provided direct molecular evidence for certain natural characteristics, such as homothallic reproduction and drought-tolerance. Comparative genomics analysis indicated that the expansion and contraction of some protein families in the E. pusillum genome reflect the specific relationship with its photosynthetic partner (D. chodati). Co-culture experiments using the lichen-forming fungus E. pusillum and its algal partner allowed the functional identification of genes involved in the nitrogen and carbon transfer between both symbionts, and three lectins without signal peptide domains were found to be essential for the symbiotic recognition in the lichen; interestingly, the ratio of the biomass of both lichen-forming fungus and its photosynthetic partner and their contact time were found to be important for the interaction between these two symbionts.

Conclusions: The present study lays a genomic analysis of the lichen-forming fungus E. pusillum for demonstrating its general biological features and the traits of the interaction between this fungus and its photosynthetic partner $D$. chodatii, and will provide research basis for investigating the nature of its drought resistance and symbiosis.
\end{abstract}

Keyword: Mycobiont, Phycobiont, Lichenization, Symbiosis, Symbiosis-related gene, Photosynthetic products

\section{Background}

A lichen is a symbiotic association of a fungus (mycobiont) and a photosynthetic partner (photobiont), which may be an alga (phycobiont) or a cyanobacterium (cyanobiont). In the association the fungus produces a thallus, or body, within which the photobionts are housed [1]. Around 20\% of all Fungi and 40\% of all Ascomycota are lichen-forming. Recent estimates of global diversity suggest that there are between 17,500 and 20,000 species [2].

\footnotetext{
* Correspondence: wanglei@nankai.edu.cn; weijc2004@126.com

${ }^{\dagger}$ Equal contributors

${ }^{3}$ TEDA School of Biological Sciences and Biotechnology, Nankai University,

Tianjin 300457, China

${ }^{1}$ State Key Laboratory of Mycology, Institute of Microbiology, Chinese

Academy of Sciences, Beijing 100101, China

Full list of author information is available at the end of the article
}

Most lichens and isolated lichen-forming fungi grow extremely slow, but the lichen-symbiosis is a very successful association as lichens can survive in almost all adverse terrestrial conditions [3]. They are also famous for their particular secondary products, which are frequently used as antibacterial and antiviral compounds $[4,5]$. The lichen-forming fungi differ from non-lichenized fungi by their adaptations to symbiosis with photobiont [6]. This mutualistic association, as called lichenization, is one of the most important fungal lifestyles and the lichenization, considered by some researchers, has evolved many times in the phylogeny of fungi $[7,8]$, and also some major fungal lineages may have derived from lichen symbiotic ancestors [9].

The principal problem about lichenization is the necessity of fungal propagules meeting a suitable photosynthetic

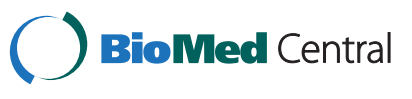

(c) 2014 Wang et al.; licensee BioMed Central Ltd. This is an Open Access article distributed under the terms of the Creative Commons Attribution License (http://creativecommons.org/licenses/by/2.0), which permits unrestricted use, distribution, and reproduction in any medium, provided the original work is properly cited. The Creative Commons Public Domain Dedication waiver (http://creativecommons.org/publicdomain/zero/1.0/) applies to the data made available in this article, unless otherwise stated. 
partner for the resynthesis of the symbiosis $[3,10]$. The recognition step is complicated, involving many morphological and molecular changes. Scanning electron microscopy (SEM) has been used to investigate the changes in morphology during the early resynthesis of the lichen thallus [11-13]. However, few studies have explored the resynthesis events in lichen using molecular tools. Previous studies suggest that the mycobiont-derived lectins (sugar-specific, cell agglutinating proteins) may play a key role in recognition [14-17] between both symbionts.

The interdependent relationship between mycobiont and photobiont is the foundation of lichenization, which required for both symbionts to maintain each other. In the lichen thallus, the photobiont provides its mycobiont with photosynthetic products [18,19], previous reports showed that lichen-forming fungi absorb polyol (ribitol, sorbitol, and erythritol) or glucose from algae or cyanobacteria, respectively [20,21], and in most green algae lichens, the hyphae of the mycobionts wrap tightly around photobiont cells, thereby protecting the photobiont cells from a range of biotic and abiotic stress, including drought, high light and mechanical damage. The protection from light-injury is associated with secondary metabolic substances, such as melanins, produced by lichen-forming fungi [22]. However, little is known about the signals and mechanisms that lead to symbiotic recognition and maintenance in lichen, although it can be predicted that some metabolic products and macromolecules are essential.

The whole life cycle of lichen is rarely observed in the laboratory or in nature $[11,13]$. The detail of lichenization, whereby a lichen-forming fungus contacts with a compatible photosynthetic partner, recognizes it and captures it, has become a hot topic in recent studies [23,24]. Endocarpon pusillum is the most successful cases on artificial resynthesis of the fertile (perithecia-bearing) thalli from isolated mycobiont and phycobiont [12], and it will be very useful to reveal the origin of symbiosis between fungi and photosynthetic organisms.

Endocarpon is a special genus, which have hymenial algal cells in their perithecia and the ascospores are discharged together with the hymenial algal cells [25]. The systematics and physiology of E. pusillum (Figure 1) have been studied well. The mycobiont E. pusillum exhibits much stronger desiccation-tolerant than other nonlichenized fungi as it can survive for 7 months under desiccation stress in combination with starvation stress [26]. Although a large number of fungal genomes have been published, no lichen-forming is included, and only two mitochondrial genomes from lichen-forming fungi (Peltigera membranacea and Peltigera malacea) and a transcriptome from the lichen Cladonia rangiferina have been reported until now $[27,28]$. Therefore, the genome of E. pusillum was sequenced and analyzed to ascertain the biological features of this lichen-forming fungus and the traits of lichenization.

\section{Results and discussion}

\section{General features of the genome}

The genome of the lichen-forming fungus E. pusillum was sequenced to about 78-fold coverage using both 454 and Illumina technologies (Additional file 1: Table S1). All sequences were assembled into 908 scaffolds (> $2 \mathrm{~kb}$; $\mathrm{N} 50,178 \mathrm{~kb})$ containing 1,731 contigs, with a genome size of $37.5 \mathrm{Mb}$ (Table 1), which was almost identical to the result calculated by real-time polymerase chain

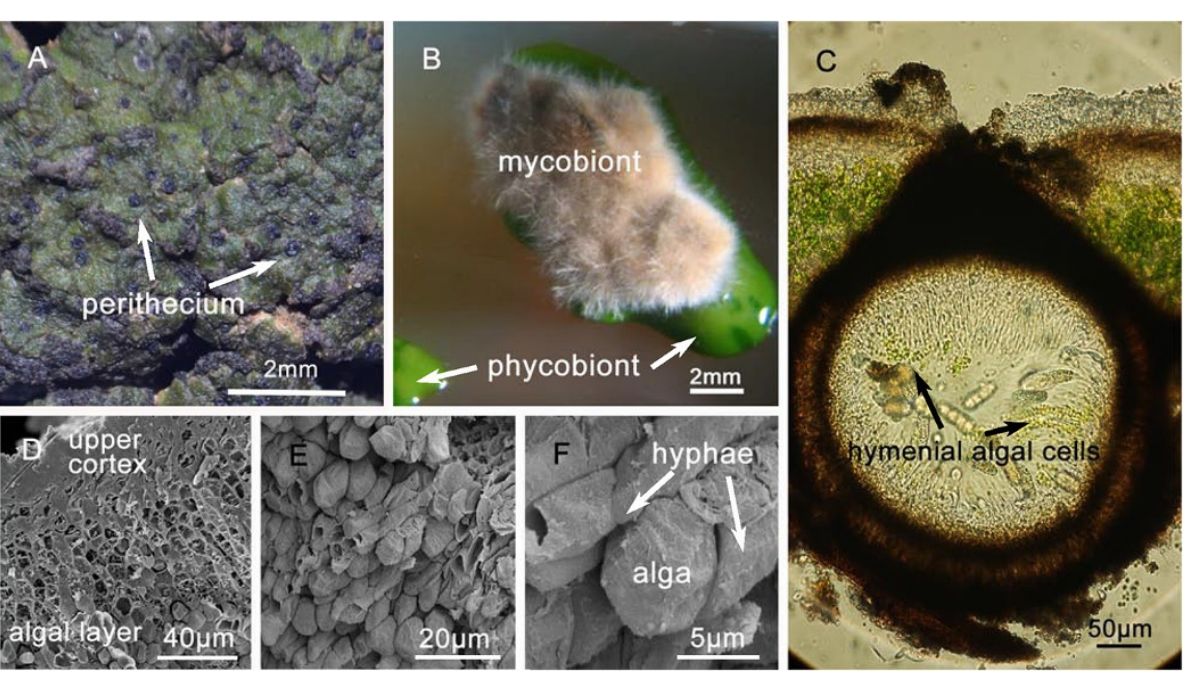

Figure 1 Endocarpon pusillum. A. The lichen E. pusillum. B. The isolated mycobiont and phycobiont [26]. C. Cross section of a perithecium with hymenial algal cells inside. D. Cross section of a thallus under scanning electron microscopy (SEM). E. The algal layer (SEM). F. An algal cell is clasped and surrounded by some hyphae (SEM). 
Table 1 Main features of the Endocarpon pusillum genome

\begin{tabular}{ll}
\hline Features & Endocarpon pusillum \\
\hline Assembly size/Mb & 37.5 \\
Scaffold N50/kb & 178 \\
Coverage/fold & 78 \\
G + C content & $46.01 \%$ \\
GC Exonic & $51.73 \%$ \\
GC Intronic & $47.05 \%$ \\
Repeat rate & $1.68 \%$ \\
Protein-coding genes & 9,285 \\
Gene density & 250.8 per Mbp \\
Exons per genes & 2.53 \\
tRNAs & 72 \\
rRNAs & 19 \\
SM (Secondary Metabolism) genes & 28 \\
TE & $15 \%$ \\
\hline
\end{tabular}

reaction (PCR) [29]. The average GC content of the genome is $46.1 \%$, and exonic region has a $4 \%$ higher GC content than the intronic region. Repetitive sequences represent $15 \%$ of the genome. A circular map was generated for the 30 largest scaffolds to illustrate the genome features more clearly (Figure 2).

The whole project has been deposited at DDBJ/EMBL/ GenBank under accession number APWS00000000. A total of 9,285 protein-coding genes were predicted, and $1,479(15.7 \%)$ of these genes have no significant matches to known proteins from public databases. A total of 2,754, 3,787 and 7,589 proteins were assigned to Gene Ontology (GO) terms, the eukaryotic orthologous groups (KOG) and functional catalogue (FunCat) databases, respectively. The distributions of the top $10 \mathrm{GO}$, KOG, and FunCat terms of the sequences are presented in Figure 3.

\section{Phylogenetic analysis of E. pusillum}

The orthologous genes from the lichen-forming fungus E. pusillum and 14 other non lichen-forming fungi whose genomes were available were identified using Inparanoid [30] with default parameters (Figure 4). Phylogenetic analysis was performed using 1,893 singlecopy orthologous genes identified among the genomes of above mentioned 15 fungi from the subkingdom Dikarya, and a linearized phylogenetic tree was constructed with estimates of the divergence times among these taxa (Figure 4). The phylogenomic analysis shows that the E. pusillum lineage is more closely related to the human pathogen Exophiala dermatitidis, which is the anamorph species of Capronia belonging to the Chaetothyriales, and the E. pusillum belongs to the

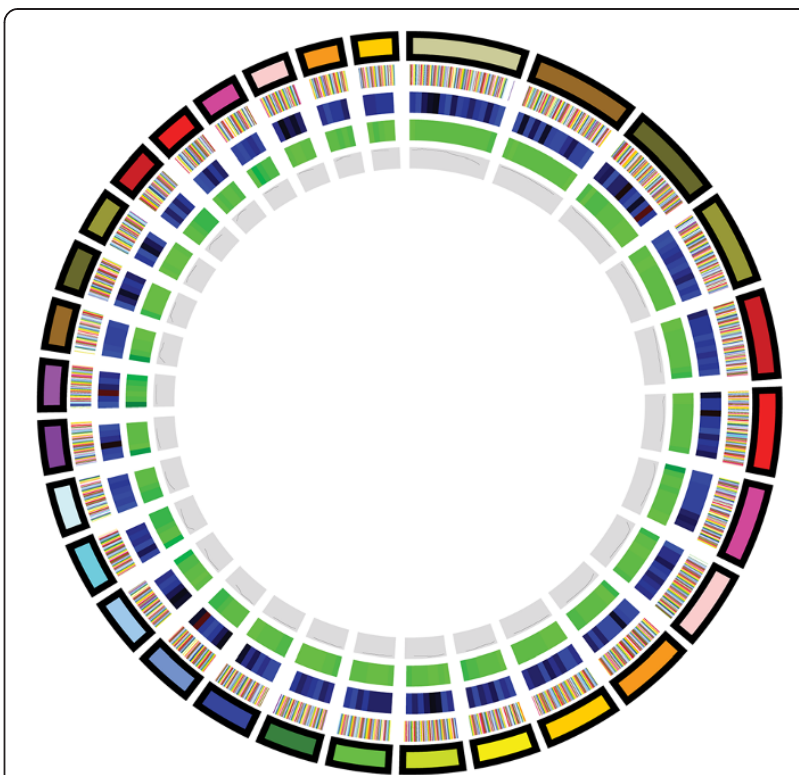

\section{A: scaffold \\ B: ORF/gene \\ C: Gene density (genes per 100kb) \\ D: Repeats coverage (\%) \\ E: GC content (GC\%, per 100kb)}

Figure 2 Genome of Endocarpon pusillum. A-E represent the circles from the outside to inside. A: Scaffolds of the genome, filtered by size ( $\geq 280 \mathrm{~Kb}$ ). B: ORFs/genes. C: Gene density represented as number of genes per $100 \mathrm{~kb}$ (non-overlapping, window size $100 \mathrm{~kb}$ ). D: Percentage coverage of repetitive sequences (non-overlapping windows, window size $100 \mathrm{~kb}$ ). E: GC content was estimated by the percent GC in $100 \mathrm{~kb}$ non-overlapping windows.

Verrucariales. Both the orders belong to the same subclass Chaetothyriomycetidae, and the divergence between the lichenized Verrucariales and nonlichenized Chaetothyriales occurred approximately 131 million years (Myr) ago (Figure 4). This result is consistence with the phylogenetic analysis for Ascomycota using ribosomal RNA [9].

\section{Repeat-induced point mutation}

Repeat-induced point mutation (RIP) is a gene silencing mechanism that can cause C-G to T-A mutations on repetitive DNA sequences, and the mutations from $\mathrm{C}$ to $\mathrm{T}$ mostly occur at CpA dinucleotides [31]. According to the method proposed by Margolin et al. [32], sequences with a high TA/AT ratio $(>0.89)$ and a low $(\mathrm{CA}+\mathrm{TG}) /$ $(\mathrm{AC}+\mathrm{GT})$ ratio $(<1.03)$ are thought to indicate RIP [33].

A quantitative alignment-based method, RIPCAL [34], was used to search for evidence for RIP in E. pusillum genome. The RIP indices of the repetitive sequence are 1.46927 and 0.697168 , and those of non-repetitive sequence are 0.565627 and 1.42277 , which indicates that 


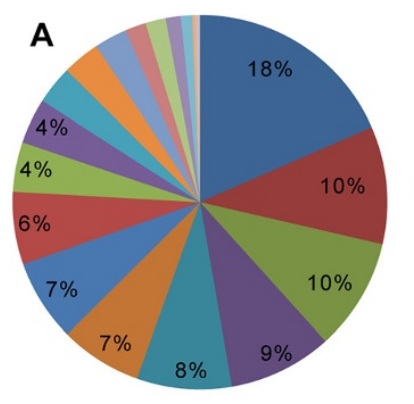

Metabolism 1400

- Cellular transport 772

- Subcellular localization 737

- Protein fate 679

Protein with binding function 621

- Transcription 537

- Cell rescue, desense and virulence 537

- Cell cycle and DNA processing 477

Interaction with the cellular environment 326

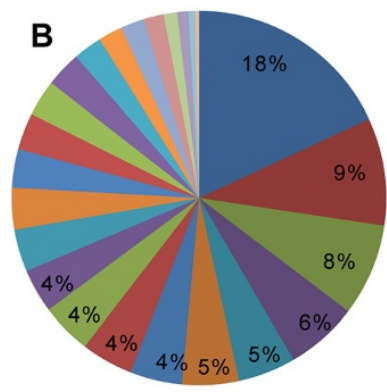

- General function prediction only 780

- Cell wall/membrane/envelope biogenesis 401

Posttranslational modification, protein turnover, chaperones 345

- Lipid transport and metabolism 269

- Function unknown 215

- Signal transduction mechanisms 211

- Cytoskeleton 194

- Secondary metabolites biosynthesis, transport and catabolism 193

Energy production and conversion 189

- Translation, ribosomal structure and biogenesis 164

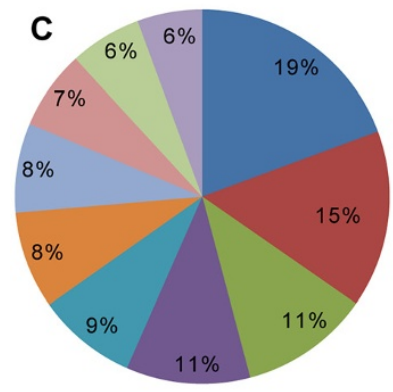

- Transmembrane transport 352

- Protein modification process 279

- Cellular protein metabolic process 204

- Translation 195

- Cellular macromolecule biosynthetic process 157

- DNA metabolic process 153

- Phosphate metabolic process 141

- Ion transport 124

- Proteolysis 113

InA processing 102

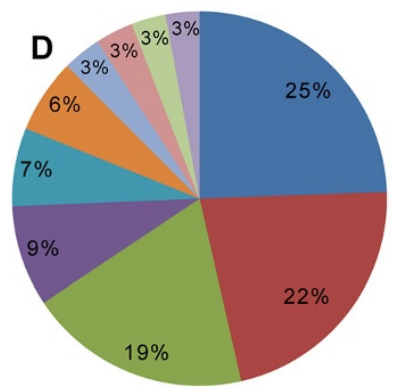

Metal ion binding 813

- Purine ribonucleotide binding 731

Adenyl nucleotide binding 639

- Hydrolase activity 290

- Kinase activity 225

- Phosphotransferase activity 213

- Peptidase activity 110

Ion transmembrane transporter activity 109

Methyltransferase activity 99

- Guanyl nucleotide binding 97

Figure 3 Functional classification for the Endocarpon pusillum genome. A. FunCat database classification in the second level. B. KOG database classification. C. The top 10 Gene Ontology biological process. D. The top 10 Gene Ontology molecular functions.

the regions of repetitive sequence in E. pusillum have undergone RIP. In addition, the percentage of genes in multigene families shows that E. pusillum has a low proportion of genes in multigene families (Figure 5A). The analysis of amino acid similarities in multigene families among eight fungi indicates that there are fewer best-matching $(\geq 80 \%)$ genes in the E. pusillum genome (Figure 5B), which implies that some genes in the multigene families in E. pusillum are RIP mutated. However, the function of RIP in lichenforming fungi still remains unclear.

\section{The mating systems and reproduction}

The genes involved in the mating process were identified in E. pusillum genome. The result shows that there is a

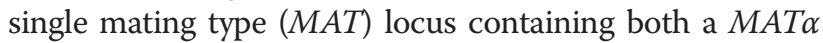
and HMG domain in the genome, which provides the molecular evidence for homothallic lifestyle of E. pusillum (Figure 6). Genes for conidiophore development and asexual reproduction were also identified, together with those involved in fruit body development and sexual reproduction (Additional file 1: Table S2), and genes with 


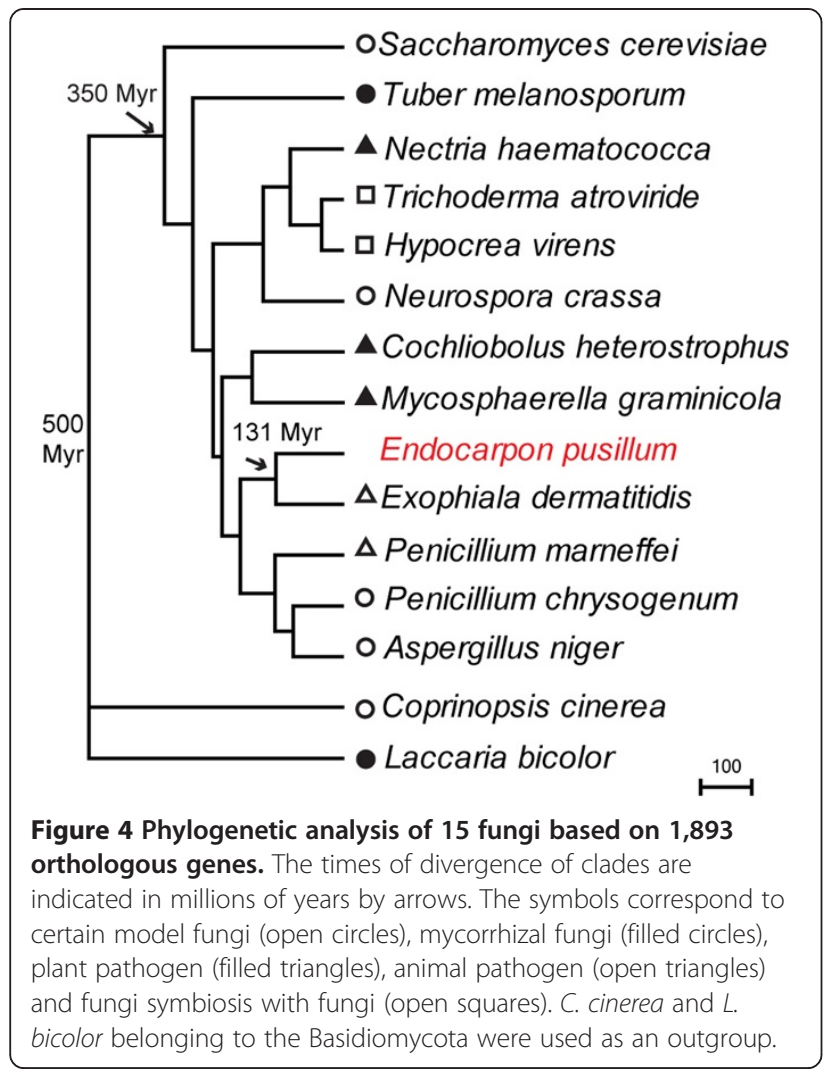

the function of pheromone precursor (alpha-factor like), pheromone receptor (for alpha-factor like pheromone), ascus development (rhamnogalacturonase B), and receptors preventing improper sexual development have been lost in E. pusillum. However, it need more experimental evidence to determine whether these missing genes contribute to the special reproduction mode of E. pusillum.

\section{Secreted proteins}

Secreted proteins are important effectors that modulate the interaction between pathogenic microbes and hosts [35-37], and many small secreted proteins (SSPs) are virulence factors [38]. However, E. pusillum has fewer secreted proteins than other phytopathogenic fungi (e.g. Fusarium graminearum, Magnaporthe oryzae and Metarhizium anisopliae) according to the blast results (Additional file 1: Table S3), and the function of $66 \%$ of SSPs is unknown. Lichen-forming fungus and pathogenic fungi are different, even though they both live with another organism and absorb nutrients from their partner. The analysis of the secreted proteins suggests that the SSP-mediated interaction between symbionts in E. pusillum is weaker than the virulence in parasitism (pathogenic fungi).

\section{Secondary metabolism}

To date, several polyketide synthase (PKS) genes have been identified in different lichen-forming fungi [39-42], but no non-ribosomal peptide synthetase (NRPS) genes have been found. Analysis of the lichen-forming fungus E. pusillum genome revealed 2 NRPS genes and 14 PKS genes (Additional file 1: Table S4). The information of genes for secondary metabolism is helpful to the research of the secondary metabolites of E. pusillum and the synthesis conditions.

\section{Candidate genes for drought tolerance}

At least 93 genes involving in these drought resistant mechanisms were identified in the genome of E. pusillum (Additional file 1: Table S5), which will provide us many important clues to resolve the question about why $E$. pusillum can survive in extreme drought environment. Recently, most studies on mechanisms about desiccation-
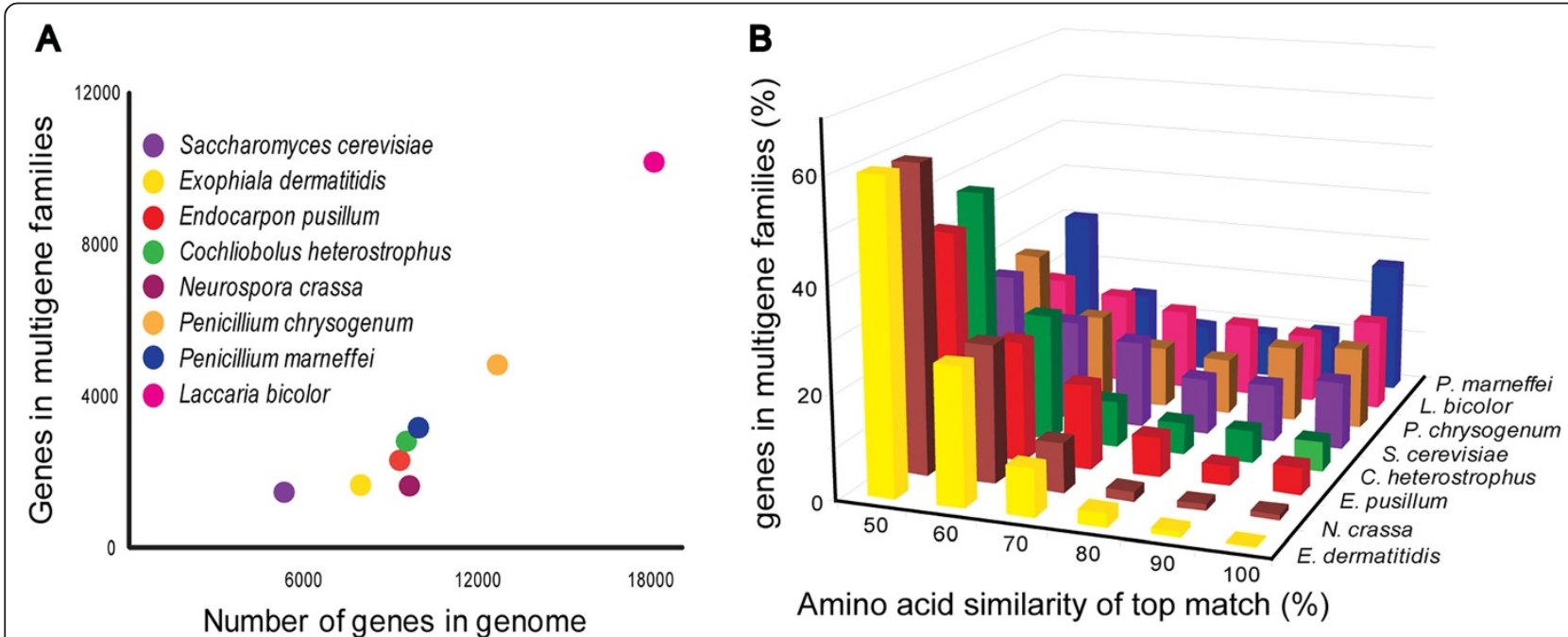

Figure $\mathbf{5}$ Proportion of genes in multi-gene families. A. The graph displays the proportion of genes in multigene families from E. pusillum and other fungi. B. Histogram of paralogous gene numbers with different levels of amino acid similarity in E. pusillum and other fungi. 


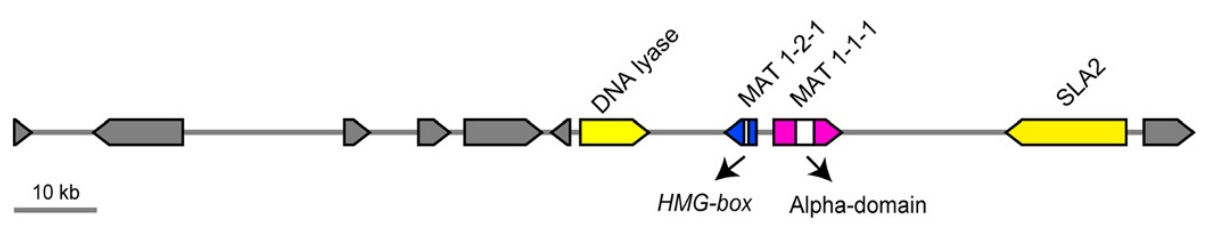

Figure 6 Configuration of the MAT locus in Endocarpon pusillum.

tolerance in lichens have focused on the scavenging reactive oxygen species [43]. However, genes involved in regulating osmotic pressure, correcting protein misfolding, and scavenging the reactive oxygen species were identified in E. pusillum genome, which were worthy of further investigation.

\section{Multigene families expansion}

Up to 1,889 protein families (containing at least two genes in all selected species) were identified from E. pusillum and 14 other fungi using Markov cluster (MCL) method. Based on BadiRate analysis, we found that 1,129 protein families were expanded and 760 protein families had undergone contraction in E. pusillum. The outlier results generated by BadiRate analysis are presented in Table 2. The expansion of these protein families might reflect specific characteristics of lichen-forming fungus E. pusillum.

\section{Protein families involved in signal transduction}

Compared with other fungi, the lichen-forming fungi are special because they can form mutualistic symbiosis with photosynthetic organisms and this specialty is reflected in its genome. Little is known about the functional genes in lichens, and most expanded protein families are function-unknown in E. pusillum (Table 2); however, it is likely that many of these expansion families are related to symbiosis. For example, the expressions of WD-repeat domain-containing proteins are up-regulated in the early developmental stages of lichen-symbiosis in Cladonia grayi [23].

Similarly, G protein-coupled receptors (GPCRs), which sense molecules outside the cell and activate signal transduction pathways inside the cell [44], are also likely to provide lichen-forming fungi with a strong ability to response to such signals, and all GPCR families have undergone obvious expansion (Table 3).

\section{Heterokaryon incompatibility protein families}

There are 261 genes in the E. pusillum genome that were annotated to have heterokaryon incompatibility (HET)-related functions, and 182 of them are homologous to those in $N$. crassa and Podospora anserina (Additional file 1: Table S6). HI (Heterokaryon incompatibility) is a common characteristic among filamentous fungi; it can prevent the formation of heterokaryotic cells in which two different genomes coexist. Once the fusion between two individuals with incompatible het loci occurs, the HET genes would trigger the $\mathrm{HI}$ reaction, which is characterized as growth inhibition, repression of asexual sporulation, hyphal compartmentation and death of the heterokaryotic cell [45-47]. However, the biological significance of $\mathrm{HI}$ is still unknown. The expansion of HET protein families suggests that E. pusillum is likely to have a strict regulation of its vegetation [48], and may represent a strategy for stable genotype by defending against the transfer of exogenous genes.

\section{Lineage-specific protein families involved in self-splicing of insertions}

The genes encoding ribonuclease $\mathrm{H}$ and transposase, which are predicted to be able to target some insertions, such as group I introns that can be stably integrated into the genome following the reverse splicing reaction [49], belong to lineage-specific multigene families in E. pusillum (Table 2).

The genomic sequencing data reveal that there are three group I introns in the large-subunit ribosomal DNA (LSU rDNA) of E. pusillum Z07020 at position 856, 2169, and 2721 (corresponding to the sequence of Pichia methylivora with NCBI accession number EU011611), and one group I intron in the small-subunit ribosomal DNA (SSU rDNA) at position 1769 (corresponding to the sequence of Saccharomyces cerevisiae with NCBI accession number Z75578).

Group I introns can self-splice themselves from an RNA transcript, requiring protein factors to facilitate the correct folding of the ribozyme core [49]. There are multiple group I introns present in the nuclear rDNA of many lichen-forming fungi [50-53], and they are considered to decrease the growth rate of lichen-forming fungi by interfering with rRNA maturation [54]. It is considered an adaption for lichenization: most lichens grow very slowly because the symbiosis would be disrupted if the mycobionts too many nutrients from the photobionts. Therefore, it is reasonable that the protein families involved in RNA reverse splicing have undergone expansion in a lichen-forming fungal genome that harbors abundant self-splicing introns.

\section{Protein families involved in transport}

The exchange of ions and metabolites between the mycobiont and photobiont is the foundation of the symbiotic 
Table 2 Expanded and lineage-specific protein families in Endocarpon pusillum

\begin{tabular}{|c|c|c|c|}
\hline Protein family ID & Number of proteins in E. pusillum & p-value & HMMPfam description \\
\hline group10696 & 20 & 0 & Hypothetical protein CIMG_07368 \\
\hline group10024 & 15 & 0 & Ankyrin and HET domain-containing protein \\
\hline group14580 & 14 & 0 & Ankyrin repeat \\
\hline group10771 & 13 & 0 & P-loop containing nucleoside triphosphate hydrolases \\
\hline group11690 & 13 & 0 & MFS general substrate transporter \\
\hline group10071 & 11 & 0 & Putative transposase \\
\hline group10011 & 10 & 0 & Hypothetical protein NECHADRAFT_87861 \\
\hline group14903 & 8 & 0 & Heterokaryon incompatibility protein \\
\hline group17019 & 7 & $1 \mathrm{E}-07$ & DNA/RNA polymerases \\
\hline group10674 & 10 & $3 \mathrm{E}-07$ & Magnesium transport protein CorA, transmembrane region \\
\hline group10674 & 10 & $3 \mathrm{E}-07$ & Hypothetical protein AN9301.2 \\
\hline group10038 & 8 & $5 \mathrm{E}-07$ & Hypothetical protein SS1G_06795 \\
\hline group10340 & 8 & $5 \mathrm{E}-07$ & Conserved hypothetical protein \\
\hline group15154 & 6 & $5 \mathrm{E}-07$ & Hypothetical protein CHGG_10108 \\
\hline group16626 & 6 & $5 \mathrm{E}-07$ & Hypothetical protein \\
\hline group18347 & 6 & $5 \mathrm{E}-07$ & Hypothetical protein \\
\hline group10002 & 9 & 2.4E-06 & Ribonuclease H-like \\
\hline group10015 & 9 & 2.4E-06 & Ankyrin repeat \\
\hline group10097 & 7 & 4.6E-06 & Ankyrin repeat \\
\hline group10201 & 7 & 4.6E-06 & ARM repeat \\
\hline group10224 & 7 & 4.6E-06 & Heterokaryon incompatibility protein \\
\hline group10843 & 7 & 4.6E-06 & Predicted protein \\
\hline group11854 & 7 & 4.6E-06 & Cytochrome P450 \\
\hline group10000 & 11 & 0.000001 & P-loop containing nucleoside triphosphate hydrolases \\
\hline group10705 & 5 & 0.000005 & Hypothetical protein \\
\hline group11683 & 5 & 0.000005 & Dimeric alpha + beta barrel \\
\hline group11909 & 5 & 0.000005 & Unnamed protein product \\
\hline group13886 & 5 & 0.000005 & Ankyrin repeat \\
\hline group15448 & 5 & 0.000005 & FabD/lysophospholipase-like \\
\hline group16624 & 5 & 0.000005 & Protein kinase-like (PK-like) \\
\hline group16962 & 5 & 0.000005 & Hypothetical protein NFIA_004500 \\
\hline group17139 & 5 & 0.000005 & Cytochrome P450 \\
\hline group18335 & 5 & 0.000005 & Predicted protein \\
\hline group18344 & 5 & 0.000005 & Conserved hypothetical protein \\
\hline group19016 & 5 & 0.000005 & Hypothetical protein \\
\hline group19022 & 5 & 0.000005 & Hypothetical protein \\
\hline group10704 & 8 & $1.78 \mathrm{E}-05$ & Conserved hypothetical protein \\
\hline group10239 & 6 & 3.81E-05 & P-loop containing nucleoside triphosphate hydrolases \\
\hline group10495 & 6 & 3.81E-05 & Unnamed protein product \\
\hline group10677 & 6 & $3.81 \mathrm{E}-05$ & Unnamed protein product \\
\hline group11482 & 6 & 3.81E-05 & Predicted protein \\
\hline group11606 & 6 & $3.81 \mathrm{E}-05$ & Hypothetical protein AOR_1_1448144 \\
\hline group15933 & 6 & 3.81E-05 & Purine and uridine phosphorylases \\
\hline group16361 & 6 & 3.81E-05 & Hypothetical protein SS1G_13793 \\
\hline
\end{tabular}


Table 2 Expanded and lineage-specific protein families in Endocarpon pusillum (Continued)

\begin{tabular}{|c|c|c|c|}
\hline group16513 & 6 & $3.81 \mathrm{E}-05$ & Conserved hypothetical protein \\
\hline group17376 & 6 & $3.81 \mathrm{E}-05$ & Hypothetical protein \\
\hline group10014 & 9 & $4.84 \mathrm{E}-05$ & POZ domain \\
\hline group10175 & 9 & 4.84E-05 & Hypothetical protein CIMG_05613 \\
\hline group10238 & 4 & 4.94E-05 & WD40 repeat-like \\
\hline group11337 & 4 & 4.94E-05 & TPR-like \\
\hline group12140 & 4 & 4.94E-05 & WD40 repeat-like \\
\hline group16268 & 4 & 4.94E-05 & Hypothetical protein MGYG_01629 \\
\hline group17166 & 4 & 4.94E-05 & Predicted protein \\
\hline group17167 & 4 & 4.94E-05 & Alpha/beta-Hydrolases \\
\hline group17374 & 4 & 4.94E-05 & Hypothetical protein FRAAL5044 \\
\hline group17553 & 4 & 4.94E-05 & Protein kinase-like (PK-like) \\
\hline group17955 & 4 & 4.94E-05 & Conserved hypothetical protein \\
\hline group18350 & 4 & 4.94E-05 & Hypothetical protein CHGG_08502 \\
\hline group19010 & 4 & 4.94E-05 & NTF2-like \\
\hline \multicolumn{4}{|c|}{ Lineage-specific protein families } \\
\hline Protein family ID & Number of proteins in E. pusillum & p-value & Pfam description \\
\hline group19669 & 4 & 4.94E-05 & Ribonuclease H-like \\
\hline group19844 & 4 & 4.94E-05 & Transposase \\
\hline group19847 & 4 & 4.94E-05 & Hypothetical protein \\
\hline group19848 & 4 & 4.94E-05 & Hypothetical protein \\
\hline group19850 & 4 & 4.94E-05 & Protein kinase-like (PK-like) \\
\hline group19853 & 4 & 4.94E-05 & Ankyrin repeat \\
\hline
\end{tabular}

association. For this reason, genes encoding transporter proteins are expected to exhibit some traits in the lichenforming fungus genome. There are 10 genes belonging to the magnesium transport protein CorA family, which showed significant expansion in the E. pusillum genome (Table 2). The CorA proteins were the first family to be identified that could transport $\mathrm{Mg}^{2+}$ in bacteria $[55,56]$. The mechanism of action of the CorA family has been well characterized in yeast and members of this family can transfer $\mathrm{Mg}^{2+}$ both into and out of the cell [57]. Magnesium is the most important divalent cation in cells, and is particularly important for photosynthesis [58]. Magnesium deficiency has been reported to affect plant photosynthesis

Table 3 Evolutionary changes of GPCR protein families in Endocarpon pusillum

\begin{tabular}{|c|c|c|c|}
\hline $\begin{array}{l}\text { GPCRs } \\
\text { family }\end{array}$ & $\begin{array}{l}\text { Number of protein } \\
\text { in } E \text {. pusillum }\end{array}$ & $\begin{array}{l}\text { Evolutionary changes } \\
\text { in E. pusillum }\end{array}$ & Annotation \\
\hline Class A & 6 & Gain & $\begin{array}{l}\text { Rhodopsin-like } \\
\text { family }\end{array}$ \\
\hline Class B & 2 & Gain & Secretin receptor \\
\hline Class D & 5 & Gain & $\begin{array}{l}\text { Fungal mating } \\
\text { pheromone } \\
\text { receptor }\end{array}$ \\
\hline Class E & 1 & Gain & cAMP receptor \\
\hline
\end{tabular}

and growth $[59,60]$. In the lichen thallus, the special structure of the symbionts (Figure 1D-F) makes it difficult for algal cells to absorb magnesium from the environment. However, genes for magnesium transport protein are expanded in E. pusillum, which led us to suspect that during symbiosis the mycobiont could provide magnesium to the phycobiont to meet the needs of their life cycles.

A striking finding is that most nitrogen transporter families are expanded but most sugar transporter families have been lost from the E. pusillum genome (Table 4). Though the mechanisms of substance transfer in lichen are not completely understood, it has been reported that the mycobiont absorbs certain carbohydrates generated by photosynthesis of the photobiont [61]. The reduction of sugar transporter genes, especially those for common sugars, such as glucose and fructose, which can be utilized by many organisms, suggests that the mycobiont simply absorbs certain uncommon carbohydrates from their photosynthetic partner. Therefore, the genes for many unnecessary sugar transporters have been lost during evolution. The lichen-forming fungi do not rely on common sugars because these carbon sources can be used by numerous microorganisms and lichen cannot compete with them for its slow growth and metabolism. 
Table 4 Evolutionary changes of transporter protein families in Endocarpon pusillum (partial results)

\begin{tabular}{|c|c|c|c|}
\hline $\begin{array}{l}\text { Transporter } \\
\text { family }\end{array}$ & $\begin{array}{l}\text { Number of } \\
\text { protein in } \\
\text { E. pusillum }\end{array}$ & $\begin{array}{l}\text { Evolutionary } \\
\text { changes in } \\
\text { E. pusillum }\end{array}$ & Annotation \\
\hline 1.A.11.3.3 & 3 & Gain & $\begin{array}{l}\text { Ammonium transporter- } \\
\text { Hebeloma cylindrosporum }\end{array}$ \\
\hline 2.A.3.10.20 & 1 & Gain & $\begin{array}{l}\text { Lysine/arginine permease- } \\
\text { Candida albicans }\end{array}$ \\
\hline 2.A.3.4.2 & 16 & Gain & $\begin{array}{l}\text { Gaba permease-Emericella } \\
\text { nidulans-Aspergillus nidulans }\end{array}$ \\
\hline 2.A.3.8.4 & 6 & Gain & $\begin{array}{l}\text { High affinity methionine } \\
\text { permease-Saccharomyces } \\
\text { cerevisiae }\end{array}$ \\
\hline 2.A.39.3.3 & 1 & Gain & $\begin{array}{l}\text { Uridine permease- } \\
\text { Saccharomyces cerevisiae }\end{array}$ \\
\hline 8.A.9.1.1 & 3 & Gain & $\begin{array}{l}\text { Amino acid transport related } \\
\text { protein (RBAT)-Oryctolagus } \\
\text { cuniculus }\end{array}$ \\
\hline 2.A.1.1.10 & 0 & Loss & $\begin{array}{l}\text { Maltose permease MAL6T- } \\
\text { Saccharomyces cerevisiae }\end{array}$ \\
\hline 2.A.1.1.11 & 1 & Loss & $\begin{array}{l}\text { General alpha-glucoside } \\
\text { permease-Saccharomyces } \\
\text { cerevisiae }\end{array}$ \\
\hline 2.A.1.1.33 & 0 & Loss & $\begin{array}{l}\text { Hexose transporter- } \\
\text { Kluyveromyces lactis }\end{array}$ \\
\hline 2.A.1.1.38 & 2 & Loss & $\begin{array}{l}\text { Sugar transporter STL1- } \\
\text { Saccharomyces cerevisiae }\end{array}$ \\
\hline 2.A.1.1.39 & 3 & Loss & $\begin{array}{l}\text { High-affinity glucose } \\
\text { transporter-Kluyveromyces } \\
\text { lactis }\end{array}$ \\
\hline 2.A.1.1.57 & 1 & Loss & $\begin{array}{l}\text { Monosaccharide transporter- } \\
\text { Aspergillus niger }\end{array}$ \\
\hline 2.A.1.1.58 & 0 & Loss & $\begin{array}{l}\text { Monosaccharide transporter- } \\
\text { Aspergillus niger }\end{array}$ \\
\hline 2.A.1.1.68 & 0 & Loss & $\begin{array}{l}\text { Glucose transporter/Sensor } \\
\text { OS-Pichia stipitis }\end{array}$ \\
\hline 2.A.1.1.9 & 0 & Loss & $\begin{array}{l}\text { Lactose permease-Kluyvero } \\
\text { myces lactis }\end{array}$ \\
\hline 2.A.1.2.23 & 1 & Loss & $\begin{array}{l}\text { Fructose facilitator- } \\
\text { Zygosaccharomyces bailii }\end{array}$ \\
\hline
\end{tabular}

By contrast, the expansion of nitrogen transporters suggests that the lichen-forming fungi need to transfer (export or import) various nitrogen sources. Nitrogen is an indispensable substance for the growth of organisms, and lichens whose photosynthetic partners are green algae must obtain inorganic and organic nitrogen [62-64]. There is no evidence for nitrogen transfer between symbionts in lichen. However, owing to the particular structure of lichen thallus in which the photobiont cells are tightly entwined by mycelia (Figure 1D-F) and the photobiont cells cannot absorb substances from their surroundings directly, it can be deduced that the necessary components for their growth, such as ions and nitrogen sources, must be transferred from the mycobiont to the photobiont. The phycobiont may be have a preference for certain forms of nitrogen; for example, in the alga-bacteria association, the algae prefer $\mathrm{NH}_{4}^{+}$and $\mathrm{NO}_{3}^{-}$, which are release by bacteria when cultured in organic nitrogen conditions [65]. Thus, the mycobiont may absorb and transform the nitrogen forms that are preferred by its photosynthetic partner. Therefore, the expansion of nitrogen transporters should be related to this physiological process. Recently, it was reported that the ammonium transporter, MEP- $\alpha$, in lichen-forming fungi was obtained though horizontal gene transfer [66], which can partly explain the mechanism of the expansion of the nitrogen transporter superfamily. This gene appears to have been lost in some groups of lichens, such as in those that are symbiotic with nitrogenfixing cyanobacteria or those that inhabit high-nitrogen niches [67]. However, for the lichens whose photobiont is a green alga that cannot fix nitrogen, the expansion of nitrogen transporter families is of great significance in promoting the growth of the lichen thallus, as seen in E. pusillum.

Expression analysis of symbiosis-related genes by quantitative real-time PCR (qRT-PCR)

A qRT-PCR experiment was performed to determine the changes of some symbiosis-related genes in the lichenforming fungus at transcription level when E. pusillum pre-contacted with its photosynthetic partner, Diplosphaera chodatii.

\section{Symbiosis-related genes selection}

Thirty-two genes encoding lectins were identified in the E. pusillum genome. They belong to four superfamilies: concanavalin A-like lectin, fucose-specific lectin, mannosebinding lectin and ricin B-related lectin. For the qRT-PCR assay, six lectin genes were selected as representatives of the four superfamilies, according to the difference in the number of transmembrane helices and signal peptides (Additional file 1: Table S7).

The expansions of nitrogen transporters and the contractions of sugar transporters imply that they are closely related to maintenance of both symbionts. Hence, certain genes encoding these transporters were chosen for the qRT-PCR assay. Among them, two ammonium transporters and one nitrate transporter that displays high homology to those in other fungi (Additional file 1: Table S8) were included. It has been reported that eight sugar transporters are able to transfer photosynthesis products in other fungi, and they are predicted to be functional at the interface of lichen association [68-75]. Thus, the homologous proteins were identified in the E. pusillum genome (Additional file 1: Table S9). The genes sharing homology with known transporters were obtained using BlastP and each of them appeared in several BlastP results; their expressions were determined by 
the qRT-PCR assay (Additional file 1: Table S10). Nitrogen metabolism and sugar metabolism in fungal cells would be active after nitrogen and carbohydrates were assimilated or transferred. Therefore, genes encoding glutamate synthase and nitrite reductase (Additional file 1: Table S8), and that encoding the Golgi GDP-mannose transporter, which is functional in the glycosylation of secreted proteins [76] and five enzymes involved in galactose and nucleotide sugar metabolism (Additional file 1: Table S10) were also included. The gene encoding the tetracycline resistance protein was chosen as a control, because it recognizes and exports tetracycline from the cell $[77,78]$ and is expected to show no expression change under the experimental conditions in the present study.

\section{Differences in expression levels of genes involved in symbiosis under co-culture conditions}

From the results presented in Figure 7, the expression levels of most genes increased only under the condition for experimental group IV (Table 5) (weight ratio of lichenforming fungus and phycobiont is $10: 3$, and culture time is 72 hours), which indicated that the contact time and biomass ratio of both symbionts affects their recognition and nutrient transfer significantly.

Three lectin genes (F481_01961, F481_04092, F481_ 02882) showed significant increases ( $\log _{2}$ fold change $>2$ ) in their expression level in experiment group IV compared with the control group B (only the mycobiont was cultured in BBM for $72 \mathrm{~h}$ ) (Table 5; Figure 7). Interestingly, the common aspect of these lectins is that there are no predicted signal peptides in their amino acid sequences (Additional file 1: Table S7) (http://elm.eu.org) [79]. Lectins are sugar-binding proteins that play an important roles in cell recognition [80]. The first lectin discovered in lichens was that found in Peltigera canina and Peltigera polydactyla [17]. Thereafter, some studies showed that lectins secreted by lichen-forming fungi may be involved in recognizing their compatible algae
$[15,16,81]$. Lectins, as surface proteins, can directly contact compatible phycobionts, and the contact requires receptor sites on the surface of the phycobiont to which the lectins binds $[82,83]$. Recent studies on lectins in $P$. membranacea indicated that the expression of galectin lec-1 was influenced by the presence of the phycobiont [84], and the evolution of galectin lec-2 was driven by interaction with different strains of the phycobiont Nostoc [85]. Galectins, together with cellular slime mold lectin discoidin I, do not have signal peptides in eukaryotic cells and both of them have intracellular and extracellular localizations [86,87]. Our study showed that lectins without signal peptides could play a major role in symbiotic recognition and provided a practical guide for screening for lectins participating in the interaction between lichenforming fungi and their photosynthetic partners.

An ammonium transporter (F481_01640) and a nitrate transporter (F481_07695) were up-regulated $\left(\log _{2}\right.$ fold change $>2$ ) in experimental group IV (Figure 7). BBM contains nitrate ions; therefore, the up-regulation of the nitrate transporter (F481_07695) is expected. However, the up-regulation of the ammonium transporter (F481_01640) suggests that ammonium could be produced from nitrate in E. pusillum and transferred to its photosynthetic partner, because there is no ammonium ion in BBM. The differences in the expressions of glutamate synthase (F481_06302) and nitrite reductase (F481_07075) indicate that nitrogen metabolism is altered in the lichenforming fungus when it meets its compatible alga. It has been reported that algae from different lichens can utilize organic and inorganic nitrogen [62-64]. Thus, we can conclude that the pattern of nitrogen transfer in E. pusillum is that the mycobiont absorbs various nitrogen sources from the environment and can convert them to different forms in vivo to meet the algae's demand for nitrogen, based on the expansion of nitrogen transporter families in E. pusillum genome and the result of co-culture experiments.

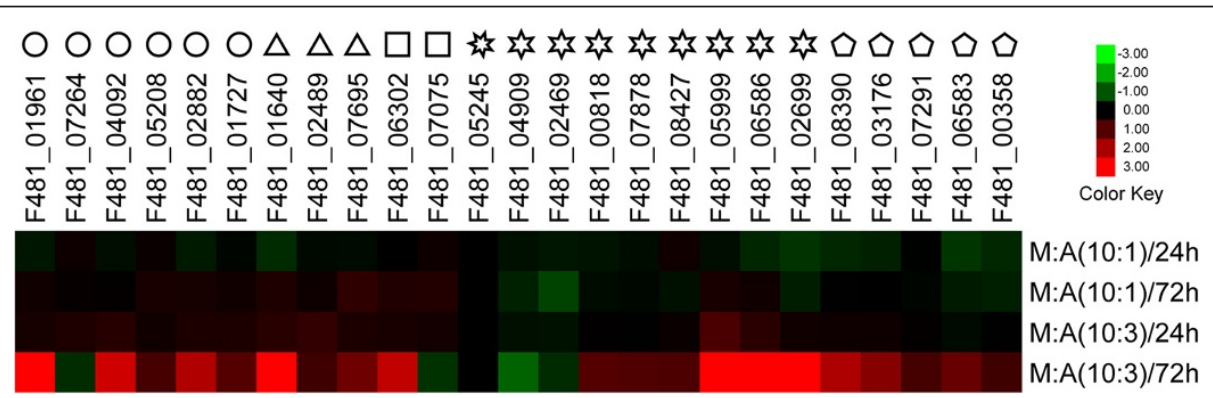

Figure 7 Relative transcription levels of certain symbiosis-related genes in Endocarpon pusillum when cultured with Diplosphaera chodatii. The names of the genes are listed on the top of the picture. Circles represent genes encoding lectins, triangles represent $\mathrm{N}$ transporter genes, squares represent gene encoding enzymes of nitrogen metabolism, a heptagon represents the tetracycline resistance protein gene, hexagons represent sugar transporter genes, and pentagons represent genes encoding enzymes of sugar metabolism. The culture conditions are displayed at the right of the picture, in which the ratios of mycobiont $(M)$ and phycobiont $(A)$ and incubation time are given. The $\log _{2}$ relative expression with respect to the control group is illustrated in the heat map. 


\begin{tabular}{|c|c|c|c|}
\hline $\begin{array}{l}\text { Experiment } \\
\text { group }\end{array}$ & Sample & $\begin{array}{l}\text { Weight ratio } \\
\text { (mycobiont: } \\
\text { Phycobiont) }\end{array}$ & $\begin{array}{l}\text { Incubation } \\
\text { time (h) }\end{array}$ \\
\hline Control A & Mycobiont & - & 24 \\
\hline Control B & Mycobiont & - & 72 \\
\hline Control C & Phycobiont & - & 72 \\
\hline | & $\begin{array}{l}\text { Mycobiont + } \\
\text { phycobiont }\end{array}$ & $10: 1$ & 24 \\
\hline$\|$ & $\begin{array}{l}\text { Mycobiont + } \\
\text { phycobiont }\end{array}$ & $10: 3$ & 24 \\
\hline III & $\begin{array}{l}\text { Mycobiont + } \\
\text { phycobiont }\end{array}$ & $10: 1$ & 72 \\
\hline IV & $\begin{array}{l}\text { Mycobiont + } \\
\text { phycobiont }\end{array}$ & $10: 3$ & 72 \\
\hline
\end{tabular}

The lichen-forming fungus cannot obtain any organic nutrition from BBM. However, six of the symbiosisrelated sugar transporter genes (F481_00818, F481_ 07878, F481_08427, F481_05999, F481_06586, and F481_02699) show significant differences in expression in experiment group IV (Figure 7). This suggests that some carbohydrates are released into the BBM by D. chodatii, and the transporters encoded by these genes may be responsible for transferring these carbohydrates into the fungal cells. The upregulation of the expression of the Golgi GDP-mannose transporter (F481_08390) under experimental group IV conditions, bearing in mind that a previous study proved that this transporter participates in glycosylation [76], indicated that the sugar metabolic pathway is active in E. pusillum after obtaining carbohydrates. Furthermore, the enzymes (F481_03176, F481_ 07291, F481_06583, and F481 00358) involved in galactose and nucleotide sugar metabolism also showed high expressions levels, which demonstrated that the carbohydrates produced by the alga and absorbed by the fungus are indeed used for fungal cell life activities.

\section{Native and non-native sugars utilized by $E$. pusillum}

The carbohydrates used for growth and metabolism of lichen-forming fungus originate from the photosynthetic products of its photosynthetic partner, however, the forms of the photosynthetic products absorbed by different lichen-forming fungi vary depending on their different photobionts. It has been report that lichenforming fungi absorb many polyols or glucose from algae or cyanobacteria, respectively [20,21], and the photosynthetic product transferred from $\mathrm{D}$. chodatii to E. pusillum was sorbitol [20]. Additionally, previous studies showed that some monosaccharides, such as glucose, and disaccharides, such as trehalose and sucrose, were transferred between non-lichenized symbionts [68-75]. Because some homology structures are frequently found in different sugar transporters from diverse fungi, the specificities of these transporters may be low. Therefore, 11 different carbohydrates were used to confirm the function of sugar transporters in E. pusillum and the potential carbohydrates transferred into this fungus.

The most significant up-regulation in expression of the examined genes was in the sample with trehalose for 24 hours. However, the high expression levels were not maintained over the next 48 hours (Figure 8 ). This suggests that trehalose cannot be absorbed by the lichenforming fungus as an energy source, but is likely to be a signal molecule for the activation of the gene expression in E. pusillum. Trehalose is involved in many functions besides osmoprotection [88], and acts as a signal molecule that is possibly exported from bacteria to plants to regulate the carbon and nitrogen metabolism of plants in plant-bacteria interactions [89]. Trehalose can be

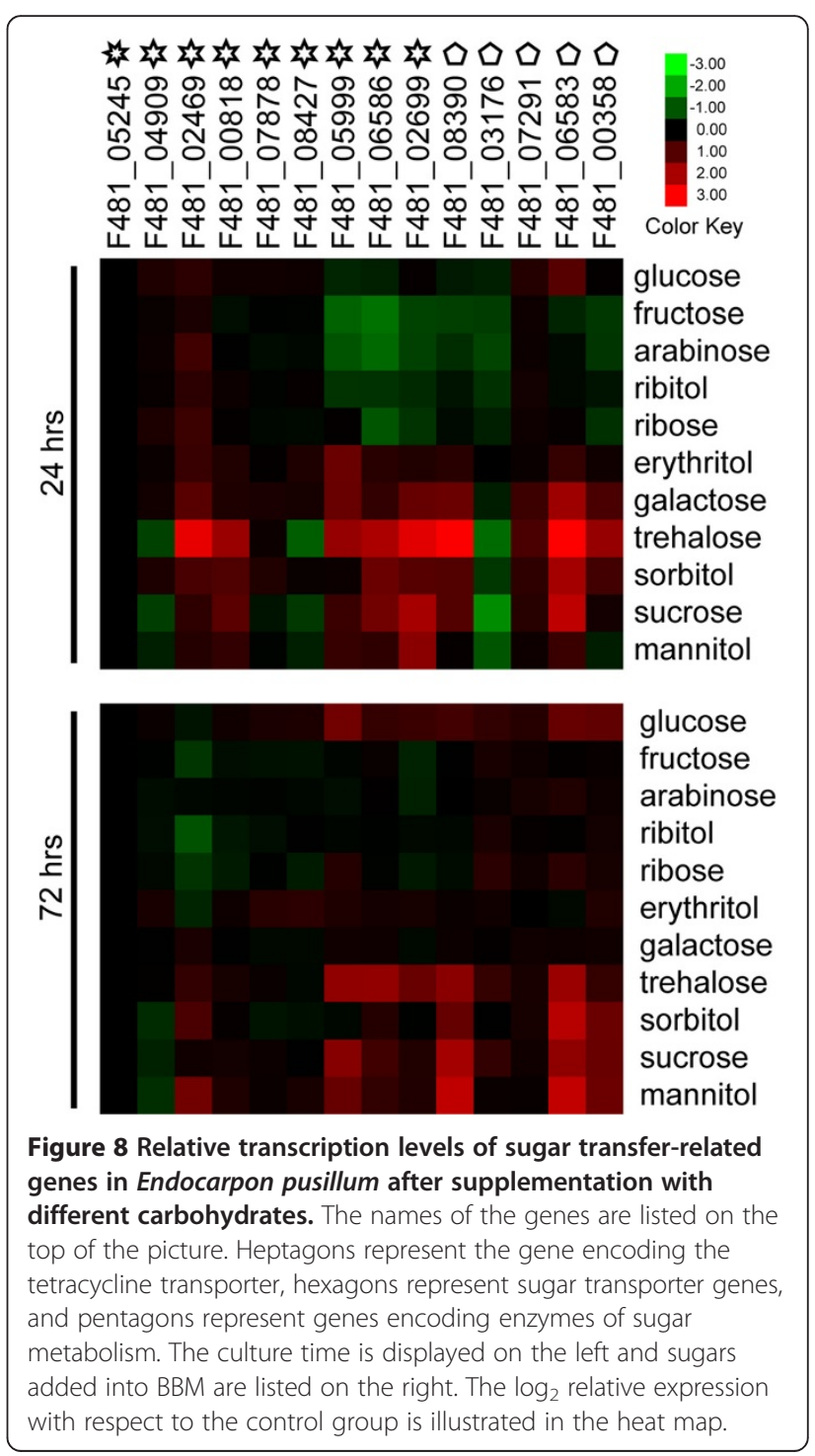


converted into trehalose-6-phosphate (T6P), which inhibits hexokinase activity and regulates glycolysis. Over expression of the trehalose 6-phospate synthase (TPS) gene induces the expression of several genes involved in stress tolerance, and carbon and nitrogen metabolism $[90,91]$. In the alga-invertebrate association, trehalose produced by the alga was shown to be present in certain symbiotic interfaces [92]. Although no research has shown a link between trehalose and lichen symbiosis interaction, our results suggest that trehalose may act as a signal molecule and would play an important role in the symbiotic interaction in E. pusillum.

Four carbohydrates (glucose, sucrose, sorbitol, and mannitol) increased the transcription levels of sugar transporters or enzymes involved in sugar metabolism in E. pusillum at 24 and 72 hours (Figure 8). These results suggest that these carbohydrates maintain the metabolism of the lichen-forming fungus over a long period, which implies that E. pusillum may absorb them as its carbon sources through some common sugar transporters. Although the transcription levels of some genes slightly fluctuated at 24 and 72 hours in the presence other sugars (arabinose, erythritol, fructose, galactose, ribitol and ribose) in the BBM, no genes exhibited a clear rising trend compared with the control group, especially those involved in sugar metabolism (Figure 8). This indicates that these sugars cannot be utilized as carbon sources by E. pusillum.

The transcription levels of some sugar transporters, such as F481_05999, F481_06586, and F481_2699, were up-regulated when various sugars were added to the $\mathrm{BBM}$, indicating that they can transfer more than one carbohydrate into E. pusillum. Some genes showed different changes in their transcription levels, either in trend or extent, compared with those in the co-culture experiment. For example, sugar transporter F481_02469 showed no differential expression in the co-culture experiment, but was up-regulated slightly under some sugars treatments. In addition, the transcription levels of sugar transporters F481_05999, F481_06586, and F481_02699 were up-regulated more obviously in the co-culture experiment (Figures 7 and 8). These phenomena imply that there is some induction mechanism between the symbionts; i.e., the expressions of certain genes in a lichen-forming fungus are influenced by its photosynthetic partner to absorb organic carbon effectively.

Ion chromatography was used to detect glucose, sucrose, sorbitol and mannitol in the filtrates of experiment group IV, and controls $\mathrm{B}$ and $\mathrm{C}$, to determine whether they could be released by $D$. chodatii and to determine the conditions under which this alga secretes organic carbon into the BBM. Sorbitol (12.6 mg/100 mL), glucose $(0.8 \mathrm{mg} / 100 \mathrm{~mL})$ and sucrose $(0.8 \mathrm{mg} / 100 \mathrm{~mL})$ have been detected in group IV (Figure 9). Thus, sorbitol

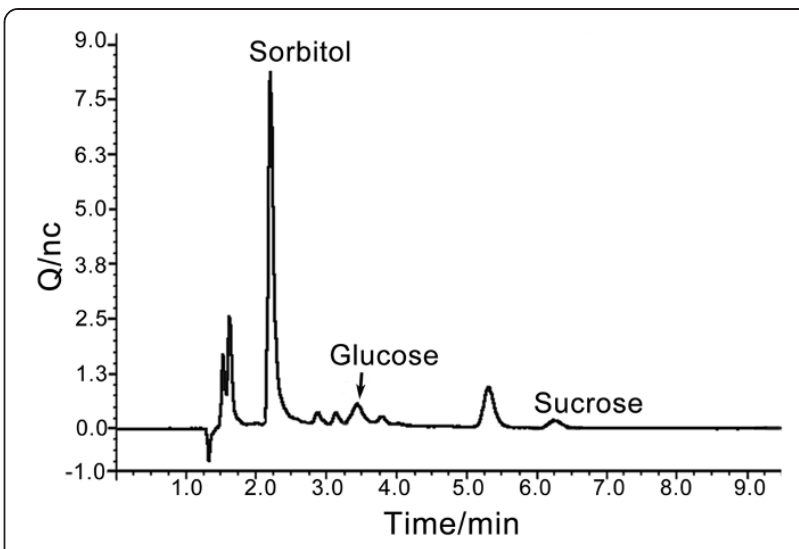

Figure 9 lon chromatogram of co-cultured sample from experimental group IV. The sample from experiment group IV (mycobiont: phycobiont $=10: 3$; culture for 72 hrs) was diluted 25 times before four carbohydrates (glucose, mannitol, sorbitol and sucrose) were measured using ion chromatography.

showed the highest accumulation; however, there were other, unidentified, carbohydrates, which suggested that the lichen-forming fungus E. pusillum preferentially absorbs sorbitol. By contrast, no mannitol was found in this sample. There were no detectable carbohydrates in the control group $\mathrm{B}$ and $\mathrm{C}$ (the phycobiont and the lichenforming fungus cultured respectively in BBM), which demonstrated that the pure cultured $D$. chodatii does not release carbon. Previous experiments for the phycobionts of Ramalina crassa and Ramalina subbreviuscula indicated that the pure cultured phycobiont released ribitol to the medium [19]. However, Hawksworth (1984) suggested that the photobiont had lost its ability to release carbohydrate after isolation from the lichen thallus, and that the lichen-forming fungus exerted some specific control on the photobiont cells that lead them to secrete carbohydrates [21]. Our result implies that E. pusillum can control the sugar export of $D$. chodatii, and that the biomass ratio and contact time are crucial for the interaction between the two symbionts.

Although mannitol is not released by D. chodatii, it can still be utilized by E. pusillum; it is likely to be because mannitol and sorbitol are isomers. This suggests that E. pusillum has the potential to use non-natural carbon sources. This phenomenon is likely to occur in other lichen-forming fungi, which would contribute to discovering the mechanism of the algal switch [93-95] and could provide clues for the evolution of lichenization.

\section{Conclusions}

Approximately 40\% of all Ascomycota are lichen-forming; thus, lichenization is regarded as one of the most important fungal lifestyles [96]. Hence, genomic information for lichen-forming fungi would expand the knowledge of fungi. In the present study, we report, for the first time, 
the characteristic of the lichen-forming fungal genome, which displays many features that are different to other fungi.

This is the first study to report that the lichen-forming fungal genome have undergone RIP. Genes for mating system, secondary metabolism, and the drought-related mechanisms were indentified in E. pusillum genome, which are worth being investigated in the future. The evolution analysis of multigene families indicated the expansion and contraction in E. pusillum genome reveal the effect of lichenization on lichen-forming fungi.

Co-culture experiments suggest that the lectins without signal peptides would be likely to play an essential role in the recognition of lichen symbiosis, and one of the most striking findings in these experiments is that an appropriate weigh ratio of lichen-forming fungus and its photosynthetic partner and sufficient contact time are vital for their recognition and mutual influence. We also confirmed that the most important natural carbon source for E. pusillum is sorbitol transferred from $D$. chodatii; however, this lichen-forming fungus can also use other non-natural carbohydrates under the pure culture condition.

A mycobiont-phycobiont interplay model is shown as Figure 10. The model reflects aspects of the recognition and interaction of the lichen thallus in E. pusillum and is likely to be applicable to other lichens, especially those whose photobionts are algae. This study provides a valuable genomic resource for future research in screening functional genes including drought-tolerance genes from lichens and would be useful for investigating the formation and divergence on the functional biology between lichenized and nonlichenized fungi.

\section{Methods}

\section{Fungal strains}

The lichen-forming fungal strain of E. pusillum Z07020 (HMAS-L-300199) was isolated by a single-spore discharge from the perithecium of lichen E. pusillum collected from Shapotou Desert Research Station (SDRS) of the Chinese Academy of Sciences (CAS) in the Tengger Desert of northern China [26]. The isolates were grown on $1.5 \%$ water agar for $1-2$ weeks, and then cultured at room temperature after transfer to potato dextrose liquid medium.

\section{Genome sequencing and assembly}

The genome of the lichen-forming fungus E. pusillum was sequenced using high-throughput next-generation sequencing technology and the sequencing platforms were Roche 454 and Illumina Solexa systems. Genomic libraries containing 8-kb inserts were constructed and 1,394,086 paired-end reads $(281.9 \mathrm{Mb})$ were generated using the 454 Roche GS FLX system. The Illumina adaptors were ligated onto the genomic DNA fragments, and DNA fragments with estimated sizes of $0.5 \mathrm{~kb}$ to $3 \mathrm{~kb}$ were selected using gel-electrophoresis. Libraries were

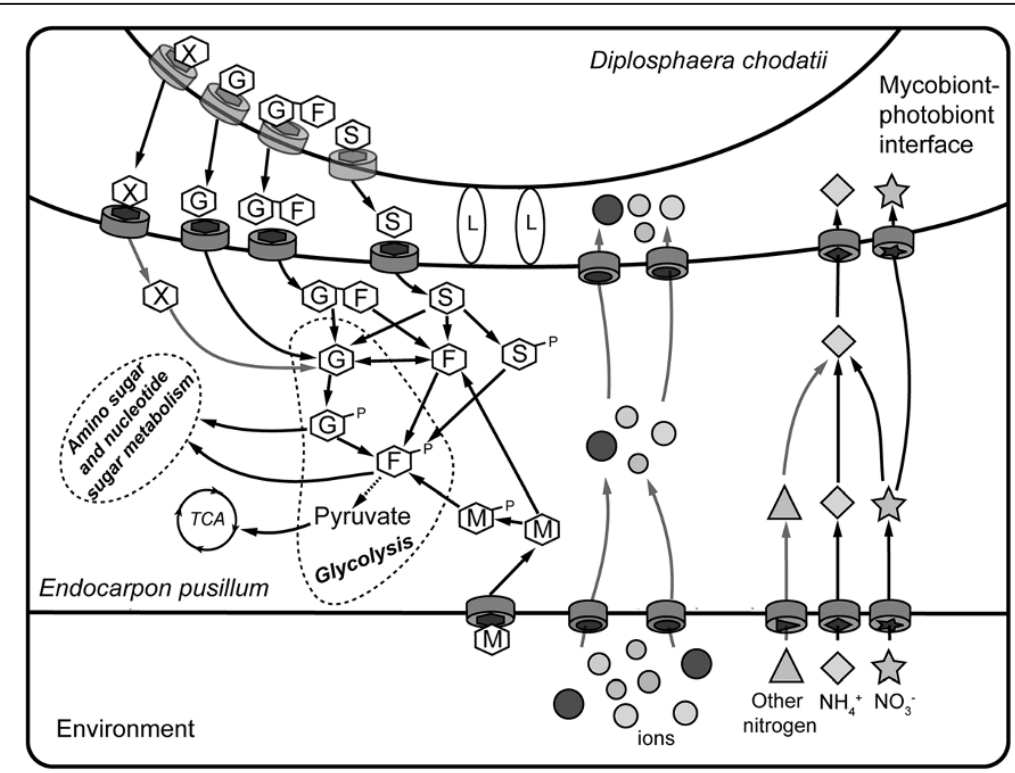

Figure 10 Summary of the interactions between symbionts in lichen Endocarpon pusillum. The lectins lacking signal peptides, which are shown as ellipse marked with $L$, act as recognition factors in the direct contact between E. pusillum and D. chodatii. After it is captured by the compatible fungal partner, the photosynthetic products sorbitol (S), glucose $(\mathrm{G})$ and sucrose $(\mathrm{G}-\mathrm{F})$ are released from the phycobiont $D$. chodatii. These sugars are then absorbed through sugar transporters of E. pusillum and converted into glucose or fructose to support fungal metabolism. In addition, there are a small amount of other uncertainty carbon sources $(X)$ released by the phycobiont, and the mycobiont can also utilize mannitol (M) from environment. At the same time, organic and inorganic nitrogen, together with various ions in the environment, are transferred into E. pusillum. In fungal cells, these substances may be converted into the forms preferred by the phycobiont and are then delivered to $D$. chodatii. 
PCR-amplified using Phusion polymerase. Sequencing libraries were denatured with sodium hydroxide and diluted in hybridization buffer for loading onto a single lane of an Illumina GA flow cell. A Solexa sequencer generated the mate-paired reads $(7,155,072$ reads, $716 \mathrm{Mb})$ and pairedend reads $(18,176,986$ reads, $1818 \mathrm{Mb})$. Solexa sequencing paired-end reads and mate-paired reads were assembled by SOAPdenovo [97], which adopts the de Bruijn graph data structure to construct contigs.

\section{Gene prediction and annotation}

We used Augustus [98], GeneID [99], and GeneMark-ES [100] programs to predict the gene models for E. pusillum. A final set of gene models was selected by EvidenceModeler [101]. An ab initio prediction was carried on using the annotated information of A. fumigatus as a reference. All predicted gene models were subjected to GO [102], KOG [103], FunCat [104] and Kyoto Encyclopedia of Genes and Genomes (KEGG) database analysis [105]. Protein domains were predicted using InterProScan [106] against various domain libraries (HMMPfam, superfamily, HMMTigr, and HMMSmart). Repetitive elements were identified by blasting against the RepeatMasker library (http://www.repeatmasker.org/). Non-coding RNAs were predicted according to the Rfam database [107], and tRNAs were predicted using tRNAscan-SE [108]. Pseudogenes and rRNAs were designated using PseudoGene [109] and RNAmmer [110] respectively.

\section{Orthologous gene and phylogeny analysis of $E$. pusillum}

The sequences of corresponding orthologous genes from 15 fungi were aligned using ClustalW [111]. A maximum parsimony (MP) phylogenomic tree was created using the concatenated amino acid sequences in phylogenetic analysis using parsimony (PAUP) [112], and a bootstrap analysis with 1000 replications was performed to evaluate the reliability of the phylogenetic tree. The divergence time between species was estimated using the r8s method [113]. The time of divergence between Ascomycota and Basidiomycota is set as 500 Myr, and the time between Pezizomycotina and Saccharomycotina was 350 Myr [114].

\section{Multigene families and evolution analysis}

The families that were absent from the most recent common ancestor were chosen to analyze the evolution of protein families [115]. Multigene families were identified using the MCL method [116]. Whole genome blast analyses against Transporter Classification Database (http:// www.tcdb.org/tcdb/) and GPCRDB (http://www.gpcr.org/ $7 \mathrm{tm} /$ ) database were performed to identify genes exhibiting difference between E. pusillum and other fungi. All proteins in the genome were blast searched against the database with an e-value cutoff of $\leq \mathrm{e}^{-10}$ and at least $40 \%$ identity over $60 \%$ coverage. A new software, BadiRate [117], was used in the evolutionary analysis of multigene families to estimate rates of gene gain and loss. Families with p-values less than 0.01 were considered to have experienced significant expansion or contraction.

\section{Mating type}

To detect the sexual cycle of E. pusillum, genes involved in the mating process, incompatibility, ascomata and conidiophore development, and HET were identified using BlastP against related genes from A. niger, A. nidulans [118], N. crassa [119] and P. anserine [120,121].

\section{Analysis of genes involved in secondary metabolism}

Genes encoding PKS, NRPS, and NRPS-PKS hybrid genes in the genome of E. pusillum were analyzed with the program SMURF (http://www.jcvi.org/smurf/index.php). Modulation analysis and domain extraction of different NRPS or PKS proteins were conducted by Blast searching against the SBSPKS database [122].

\section{Secreted proteins}

The potential secreted proteins of E. pusillum and other fungi, including F. graminearum, M. oryzae, and M. anisopliae, were predicted by SignaIP 3.0 analysis using a hidden Markov model [http://www.cbs.dtu.dk/services/ SignalP/].

\section{Quantitative RT-PCR}

RNA was extracted from cultured lichen-forming fungus E. pusillum. cDNA synthesis and relative quantitative RTPCR were carried out as described previously [28]. For each treatment, qRT-PCR was performed in an Applied Biosystems 7500 Real-Time PCR system (Applied Biosystems, USA). The data were analyzed using the $2^{-\Delta C t}$ method.

\section{Gene-stability measure of reference genes using geNORM} Vandesomepele et al. (2002) developed an algorithm named geNORM that determines the expression stability of reference genes [123]. The calculated gene-stability measure $(\mathrm{M})$ relies on the principle that the expression ratio of two ideal internal reference genes is identical in all samples, regardless of the experimental condition or cell type. Ten genes whose expressions showed no difference in comparative transcriptome data between control and drought-stress conditions (unpublished data) were chosen to determine the best reference genes (Additional file 1: Table S11). Ultimately, we chose the tetracycline resistance protein (F481_ 05245) gene as the reference gene.

\section{Treatment of samples for co-culture experiments}

Four treatments were carried out, comprising two weight ratios (10:1 and 10:3) for the lichen-forming fungus and 
phycobiont and two culture times (24 h and $72 \mathrm{~h}$ ) (Table 5), to investigate whether the ratio and contact time between the lichen-forming fungus and phycobiont has an effect on gene expression in E. pusillum when both symbionts are incubated together.

The experiment was performed in Bold's basal medium (BBM) (does not contain carbohydrate), and under $12 \mathrm{~h}$ illuminations per $24 \mathrm{~h}$, which allow the algal cells to produce carbohydrates by photosynthesis.

\section{Treatment of samples for sugar transfer experiments}

To confirm the capability of E. pusillum to utilize carbohydrates, polyols (mannitol, sorbitol, ribitol, and erythritol), monosaccharides (glucose, fructose, arabinose, ribose, and galactose) and disaccharides (trehalose and sucrose), respectively, were added to BBM containing only the lichen-forming fungus, and the transcript levels of genes involved in sugar transport and metabolism were determined after culturing for 24 and 72 hrs.

\section{Determination of photosynthetic products by ion chromatography}

Ion chromatography was used to determine glucose, sucrose, sorbitol and mannitol in co-cultured samples. The analytes were separated on a CarboPac ${ }^{\text {TM }}$ PA1 $(4 \mathrm{~mm} \times$ $250 \mathrm{~mm}$ ) anion exchange column using $200 \mathrm{mmol} / \mathrm{L}$ $\mathrm{NaOH}$ as mobile phase at flow rate of $1.0 \mathrm{~mL} / \mathrm{min}$ and detected with a pulsed amperometric detector.

\section{Availability of supporting data}

The data sets supporting the results of this article are included within the article (and its additional files).

\section{Additional file}

Additional file 1: Genomic analysis of Endocarpon pusillum. The file contains additional information on genomic properties and qRT-PCR assays, comprising 10 tables provided in separate excel sheets. Table S1 summarizes the main features of the primary sequence data. Table S2 provides information on genes encoding proteins involved in sexual and asexual reproduction in E. pusillum. Table $\mathbf{S} \mathbf{3}$ is a comparison of the number of secreted proteins between E. pusillum and other phytopathogenic fungi. Table S4 lists the domain structures of predicted E. pusillum PKS and NRPS genes. Table S5 lists the genes involving in drought resistant mechanisms in E. pusillum. Table $\mathbf{S} 6$ provides information on genes involved in heterokaryon incompatibility in E. pusillum. Table $\mathbf{S 7}$ lists the lectins measured by qRT-PCR analysis. Table S8 lists genes that encode nitrogen transporters or proteins involved in nitrogen metabolism in E. pusillum, whose transcriptions were determined by qRT-PCR analysis. Table $\mathbf{S 9}$ lists the homologous genes involved in symbiotic fungal sucrose and monosaccharide transporters in E. pusillum. Table S10 lists genes that encode sugar transporters or proteins involved in sugar metabolism in E. pusillum, whose transcriptions were determined by qRT-PCR analysis. Table S11 lists the candidate reference genes for qRT-PCR analysis in E. pusillum.

\section{Abbreviations}

BBM: Bold's basal medium; bp: Base pair; FunCat: Functionally annotation; GO: Gene ontology; GPCR: G-protein coupled receptor; HET: Heterokaryon incompatibility; HI: Heterokaryon incompatibility; HMAS: Mycological herbarium of microbiology institute,the chinese academy of sciences; KEGG: Kyoto encyclopedia of genes and genomes database; KOG: Eukaryotic clusters of orthologous groups; LSUrDNA: Large-subunit ribosomal DNA; NCBI: National center for biotechnology information; MAT: Mating-type; MCL: Markov cluster; MFS: Major facilitator superfamily; Myr: million years; NRPS: Non-ribosomal peptide synthetase; PCR: Polymerase chain reaction; PKS: Polyketide synthase; qRT-PCR: Quantitative real-time PCR; RIP: Repeat-induced point mutation; SEM: Scanning electron microscopy; SSUrDNA: Small-subunit ribosomal DNA; T6P: Trehalose-6-phosphate; TPS: Trehalose 6-phospate synthase; SSP: Small secret protein.

\section{Competing interests}

There are no competing financial interests associated with this work.

\section{Authors' contributions}

YYW performed the biological assays, analyzed the genomic and qRT-PCR data and wrote the draft manuscript. BL was in charge of the genome sequencing and gene annotation. XYZ provided the analysis of genome data. QMZ took part in writing the draft manuscript, designed the biological experiments and analyzed the data. TZ isolated and determined the strain of lichen-forming fungus E. pusillum and its phycobiont D. chodatii, and optimized their culture for the study. HL provided the genes concerning sexual cycle of fungi and constructed two color figures (Figures 1 and 10). YFY and XLZ participated in the analysis of genome data. XYH and MW assisted with the genome sequencing. LW initiated the study and finalized the manuscript. JCW initiated and designed the study, wrote parts of the manuscript, and revised and finalized the manuscript. All authors read and approved the final version of the manuscript.

\section{Acknowledgments}

This research was supported by the National Natural Science Foundation of China (No. 31070018, 81171524, 31270003, 31000010 and 31070360), the National 973 Program of China Grant (2013CB733904) and the Knowledge Innovation Program of the Chinese Academy of Sciences (KSCX2-EW-J-6).

\section{Accession number}

The whole project has been deposited at DDBJ/EMBL/GenBank under accession number APWS00000000.

\section{Author details}

${ }^{1}$ State Key Laboratory of Mycology, Institute of Microbiology, Chinese Academy of Sciences, Beijing 100101, China. ${ }^{2}$ University of Chinese Academy of Sciences, Beijing 100049, China. ${ }^{3}$ TEDA School of Biological Sciences and Biotechnology, Nankai University, Tianjin 300457, China.

Received: 7 October 2013 Accepted: 14 January 2014

Published: 17 January 2014

\section{References}

1. Ahmadjian V: The lichen symbiosis. New York: John Wiley; 1993

2. Kirk PMCP, Minter DW, Stalpers JA: Dictionary of the fungi. 10th edition. Wallingford: $\mathrm{CABl} ; 2008$.

3. Nash TH: Lichen biology. 2nd edn. Cambridge. New York: Cambridge University Press; 2008.

4. Ingolfsdottir K: Usnic acid. Phytochemistry 2002, 61:729-736.

5. Burkholder PR, Evans AW, McVeigh I, Thornton HK: Antibiotic activity of lichens. P Natl Acad Sci USA 1944, 30:250.

6. Honegger R: The lichen symbiosis - what is so spectacular about it? The Lichenologist 1998, 30:193-212.

7. Wedin M, Döring H, Gilenstam G: Saprotrophy and lichenization as options for the same fungal species on different substrata: environmental plasticity and fungal lifestyles in the Stictis-Conotrema complex. New Phytol 2004, 164:459-465.

8. Gargas A, DePriest PT, Grube M, Tehler A: Multiple origins of lichen symbioses in fungi suggested by SSU rDNA phylogeny. Science-New York then Washington 1995:1492-1492.

9. Lutzoni F, Pagel M, Reeb V: Major fungal lineages are derived from lichen symbiotic ancestors. Nature 2001, 411:937-940.

10. Rikkinen J: Molecular studies on cyanobacterial diversity in lichen symbioses. Lichens: from genome to ecosystems in a changing world MycoKeys 2013, 6:3-32 
11. Ahmadjian $V$, Jacobs JB, Russell LA: Scanning electron-microscope study of early lichen synthesis. Science 1978, 200:1062-1064.

12. Ahmadjian $\mathrm{VHH}$ : The culture and synthesis of Endocarpon pusillum and Staurothele clopima. Lichenologist 1970, 4:13.

13. Trembley ML, Ringli C, Honegger R: Morphological and molecular analysis of early stages in the resynthesis of the lichen Baeomyces rufus. Mycol Res 2002, 106:768-776.

14. Guillot J, Konska G: Lectins in higher fungi. Biochem Syst Ecol 1997, 25:203-230

15. Kardish NSL, Flemminger N, Galun M: Lectin from the lichen Nephroma laevigatum. Localization and function. Symbiosis 1991, 11:47-62.

16. Andrews GA, Chavey PS, Smith JE: Reactivity of lichen lectins with blood typed canine erythrocytes. Res Vet Sci 1992, 53:315-319.

17. Lockhart C, Rowell P, Stewart W: Phytohaemagglutinins from the nitrogen-fixing lichens Peltigera canina and P. polydactyla. FEMS Microbiology Letters 1978, 3:127-130.

18. Richardson DHS, Hill DJ, Smith DC: Lichen physiology. New Phytol 1968, 67:469-486

19. Komiya T, Shibata S: Polyols produced by the cultured phyco-and mycobionts of some Ramalina species. Phytochemistry 1971, 10:695-699.

20. Hill DJ, Ahmadjia V: Relationship between carbohydrate movement and symbiosis in lichens with Green-Algae. Planta 1972, 103:267.

21. Hawksworth DL, Hill DJ: The lichen-forming fungi. Blackie 1984, 5:62-69.

22. Gauslaa Y, Solhaug KA: Fungal melanins as a sun screen for symbiotic green algae in the lichen Lobaria pulmonaria. Oecologia 2001, 126:462-471.

23. Joneson S, Armaleo D, Lutzoni F: Fungal and algal gene expression in early developmental stages of lichen-symbiosis. Mycologia 2011, 103:291-306.

24. Suzanne Joneson FL: Compatibility and thigmotropism in the lichen symbiosis: a reappraisal. Symbiosis 2009, 47:109-115

25. Awasthi DD: A hand book of lichens. Bishen Singh Mahendra Pal Singh: Dehradun; 2000.

26. Zhang T, Wei J: Survival analyses of symbionts isolated from Endocarpon pusillum Hedwig to desiccation and starvation stress. Sci China Life SCi 2011, 54:480-489.

27. Xavier BB, Miao VPW, Jonsson ZO, Andresson OS: Mitochondrial genomes from the lichenized fungi Peltigera membranacea and Peltigera malacea: Features and phylogeny. Fungal Biol-Uk 2012, 116:802-814

28. Junttila SM, Rudd S: Characterization of a transcriptome from a non-mode organism, Cladonia rangiferina, the grey reindeer lichen, using high-throughput next generation sequencing and EST sequence data. BMC Genomics 2012, 13:575

29. Wang YY, Zhang T, Zhou QM, Wei JC: Construction and characterization of a full-length cDNA library from mycobiont of Endocarpon pusillum (lichen-forming Ascomycota). World J Microb Biot 2011, 27:2873-2884.

30. Ostlund G, Schmitt T, Forslund K, Kostler T, Messina DN, Roopra S, Frings O, Sonnhammer ELL: InParanoid 7: new algorithms and tools for eukaryotic orthology analysis. Nucleic Acids Res 2010, 38:D196-D203.

31. Cambareri EB, Jensen BC, Schabtach E, Selker EU: Repeat-Induced G-C to a-T Mutations in Neurospora. Science 1989, 244:1571-1575.

32. Margolin BS, Garrett-Engele PW, Stevens JN, Fritz DY, Garrett-Engele C, Metzenberg RL, Selker EU: A methylated Neurospora 5S rRNA pseudogene contains a transposable element inactivated by repeat-induced point mutation. Genetics 1998, 149:1787-1797.

33. Selker EU, Tountas NA, Cross SH, Margolin BS, Murphy JG, Bird AP, Freitag M: The methylated component of the Neurospora crassa genome. Nature 2003, 422:893-897.

34. Hane JK, Oliver RP: RIPCAL: a tool for alignment-based analysis of repeat-induced point mutations in fungal genomic sequences. BmC Bioinformatics 2008, 9:478-490.

35. Hogenhout SA, Van der Hoorn RAL, Terauchi R, Kamoun S: Emerging concepts in effector biology of plant-associated organisms. Mol Plant Microbe In 2009, 22:115-122.

36. Plett JM, Kemppainen M, Kale SD, Kohler A, Legue V, Brun A, Tyler BM, Pardo AG, Martin F: A secreted effector protein of laccaria bicolor is required for symbiosis development. Curr Biol 2011, 21:1197-1203.

37. Kloppholz S, Kuhn H, Requena N: A secreted fungal effector of glomus intraradices promotes symbiotic biotrophy. Curr Biol 2011 21:1204-1209.

38. Deller S, Hammond-Kosack KE, Rudd JJ: The complex interactions between host immunity and non-biotrophic fungal pathogens of wheat leaves. J plant physiol 2011, 168:63-71.
39. Armaleo D, Sun XM, Culberson C: Insights from the first putative biosynthetic gene cluster for a lichen depside and depsidone. Mycologia 2011, 103:741-754

40. Wang Y, Kim JA, Cheong YH, Joshi Y, Koh YJ, Hur JS: Isolation and characterization of a reducing polyketide synthase gene from the lichen-forming fungus usnea longissima. J Microbio/ 2011, 49:473-480.

41. Kim JA, Hong SG, Cheong YH, Koh YJ, Hur JS: A new reducing polyketide synthase gene from the lichen-forming fungus Cladonia metacorallifera. Mycologia 2012, 104:362-370.

42. Wang $Y$, Kim JA, Cheong YH, Koh YJ, Hur JS: Isolation and characterization of a non-reducing polyketide synthase gene from the lichen-forming fungus Usnea longissima. Mycol Prog 2012, 11:75-83.

43. Kranner I, Beckett R, Hochman A, Nash TH: Desiccation-tolerance in lichens: a review. Bryologist 2008, 111:576-593.

44. Gilman AG: G-Proteins - Transducers of receptor-generated signals. Annu Rev Biochem 1987, 56:615-649.

45. Glass NL, Jacobson DJ, Shiu PK: The genetics of hyphal fusion and vegetative incompatibility in filamentous ascomycete fungi. Annu Rev Genet 2000, 34:165-186.

46. Saupe SJ, Clave C, Begueret J: Vegetative incompatibility in filamentous fungi: Podospora and Neurospora provide some clues. Curr Opin Microbiol 2000, 3:608-612

47. Fedorova ND, Badger JH, Robson GD, Wortman JR, Nierman WC: Comparative analysis of programmed cell death pathways in filamentous fungi. BMC Genomics 2005, 6:177-191.

48. Saupe SJ: Molecular genetics of heterokaryon incompatibility in filamentous ascomycetes. Microbiol Mol Biol R 2000, 64:489.

49. Haugen $P$, Simon DM, Bhattacharya D: The natural history of group I introns. Trends Genet 2005, 21:111-119.

50. Gargas A, Taylor JW: Phylogeny of discomycetes and early radiations of the apothecial ascomycotina inferred from Ssu Rdna sequence data. Exp Mycol 1995, 19:7-15.

51. Bhattacharya D, Friedl T, Helms G: Vertical evolution and intragenic spread of lichen-fungal group I introns. J Mol Evol 2002, 55:74-84.

52. Gargas A, DePriest PT, Taylor JW: Positions of multiple insertions in SSU rDNA of lichen-forming fungi. Mol Biol Evol 1995, 12:208-218.

53. Hibbett DS: Phylogenetic evidence for horizontal transmission of group I introns in the nuclear ribosomal DNA of mushroom-forming fungi. Mol Biol Evol 1996, 13:903-917.

54. Depriest PT: Molecular innovations in lichen systematics - the use of ribosomal and intron nucleotide-sequences in the cladonia-chlorophaea complex. Bryologist 1993, 96:314-325.

55. Smith RL, Banks JL, Snavely MD, Maguire ME: Sequence and topology of the CorA magnesium transport systems of Salmonella typhimurium and Escherichia coli. Identification of a new class of transport protein. J Biol Chem 1993, 268:14071-14080.

56. Kehres DG, Maguire ME: Structure, properties and regulation of magnesium transport proteins. Biometals 2002, 15:261-270.

57. Liu GJ, Martin DK, Gardner RC, Ryan PR: Large Mg2 + -dependent currents are associated with the increased expression of ALR1 in Saccharomyces cerevisiae. FEMS Microbiology Letters 2002, 213:231-237.

58. Gardner RC: Genes for magnesium transport. Curr Opin Plant Biol 2003, 6:263-267.

59. Zhao H, Zhou Q, Zhou M, Li C, Gong X, Liu C, Qu C, Si W, Hong F: Magnesium deficiency results in damage of nitrogen and carbon cross-talk of maize and improvement by cerium addition. Biol Trace Elem Res 2012, 148:102-109.

60. Mcswain BD, Tsujimoto HY, Arnon Dl: Photochemical activity and components of membrane preparations from blue-green-algae.4. Effects of magnesium and chloride-lons on light-induced electron-transport in membrane fragments from a blue-green-alga. Biochimica Et Biophysica Acta 1976, 423:313-322.

61. Smith D, Muscatine L, Lewis D: Carbohydrate movement from autotrophs to heterotrophs in parasitic and mutualistic symbiosis. Biol Rev Camb Philos Soc 1969, 44:17-90.

62. Crittenden PD: The effect of oxygen deprivation on inorganic nitrogen uptake in an Antarctic macrolichen. Lichenologist 1996, 28:347-354.

63. Crittenden PD: Nutrient exchange in an Antarctic macrolichen during summer snowfall snow melt events. New Phytol 1998, 139:697-707.

64. Dahlman L, Persson J, Palmqvist K, Nasholm T: Organic and inorganic nitrogen uptake in lichens. Planta 2004, 219:459-467. 
65. Berman T, Chava S: Algal growth on organic compounds as nitrogen sources. J Plankton Res 1999, 21:1423-1437.

66. McDonald TR, Dietrich FS, Lutzoni F: Multiple horizontal gene transfers of ammonium transporters/ammonia permeases from prokaryotes to eukaryotes: toward a new functional and evolutionary classification. $\mathrm{Mol}$ Biol Evol 2012, 29:51-60.

67. McDonald TR, Mueller O, Dietrich FS, Lutzoni F: High-throughput genome sequencing of lichenizing fungi to assess gene loss in the ammonium transporter/ammonia permease gene family. Bmc Genomics 2013, 14:225.

68. Wahl R, Wippel K, Goos S, Kämper J, Sauer N: A novel high-affinity sucrose transporter is required for virulence of the plant pathogen Ustilago maydis. Plos Biol 2010, 8:e1000303.

69. Fang WG: St Leger RJ: Mrt, a gene unique to fungi, encodes an oligosaccharide transporter and facilitates rhizosphere competency in metarhizium robertsii. Plant Physiology 2010, 154:1549-1557.

70. Helber N, Wippel K, Sauer N, Schaarschmidt S, Hause B, Requena N: A versatile monosaccharide transporter that operates in the arbuscular mycorrhizal fungus glomus $\mathrm{sp}$ is crucial for the symbiotic relationship with plants. Plant Cell 2011, 23:3812-3823.

71. Voegele RT, Struck C, Hahn M, Mendgen K: The role of haustoria in sugar supply during infection of broad bean by the rust fungus Uromyces fabae. P Natl Acad Sci USA 2001, 98:8133-8138.

72. Doehlemann G, Molitor F, Hahn M: Molecular and functional characterization of a fructose specific transporter from the gray mold fungus Botrytis cinerea. Fungal Genet Biol 2005, 42:601-610

73. Wiese J, Kleber R, Hampp R, Nehls U: Functional characterization of the Amanita muscaria monosaccharide transporter, Am Mst1. Plant Biology 2000, 2:278-282

74. Polidori E, Ceccaroli P, Saltarelli R, Guescini M, Menotta M, Agostini D, Palma F, Stocchi V: Hexose uptake in the plant symbiotic ascomycete Tuber borchii Vittadini: biochemical features and expression pattern of the transporter TBHXT1. Fungal Genet Biol 2007, 44:187-198.

75. Schussler A, Martin H, Cohen D, Fitz M, Wipf D: Characterization of a carbohydrate transporter from symbiotic glomeromycotan fungi. Nature 2006, 444:933-936

76. Abe M, Noda Y, Adachi H, Yoda K: Localization of GDP-mannose transporter in the Golgi requires retrieval to the endoplasmic reticulum depending on its cytoplasmic tail and coatomer. J Cell Sci 2004, 117:5687-5696.

77. Schnappinger D, Hillen W: Tetracyclines: antibiotic action, uptake, and resistance mechanisms. Arch Microbiol 1996, 165:359-369.

78. Walsh C: Molecular mechanisms that confer antibacterial drug resistance. Nature 2000, 406:775-781.

79. Gould CM, Diella F, Via A, Puntervoll P, Gemund C, Chabanis-Davidson S, Michael S, Sayadi A, Bryne JC, Chica C, et al: ELM: the status of the 2010 eukaryotic linear motif resource. Nucleic Acids Res 2010, 38:D167-D180.

80. Sharon N, Lis H: Lectins as cell recognition molecules. Science 1989, 246:227-234.

81. Sacristan M, Millanes AM, Legaz ME, Vicente C: A lichen lectin specifically binds to the alpha-1,4-Polygalactoside moiety of urease located in the cell wall of homologous algae. Plant Signal Behav 2006, 1:23-27.

82. Galun MKN: Lectins as determinants of symbiotic specificity in lichens. Cryptog Bot 1995, 5:144-148.

83. Vivas M, Sacristan M, Legaz ME, Vicente $C$ : The cell recognition model in chlorolichens involving a fungal lectin binding to an algal ligand can be extended to cyanolichens. Plant Biol (Stuttg) 2010, 12:615-621.

84. Miao VPW, Manoharan SS, Snaebjarnarson V, Andresson OS: Expression of lec-1, a mycobiont gene encoding a galectin-like protein in the lichen Peltigera membranacea. Symbiosis 2012, 57:23-31.

85. Manoharan SS, Miao VP, Andresson OS: LEC-2, a highly variable lectin in the lichen. Symbiosis 2012, 58:91-98.

86. Liener IE, Sharon N, Goldstein IJ: The Lectins: properties, functions, and applications in biology and medicine. Orlando: Academic; 1986.

87. Barondes SH, Cooper DN, Gitt MA, Leffler H: Galectins. Structure and function of a large family of animal lectins. J Biol Chem 1994 269:20807-20810.

88. Iturriaga G, Suarez R, Nova-Franco B: Trehalose metabolism: from osmoprotection to signaling. Int J Mol Sci 2009, 10:3793-3810.

89. Suarez R, Wong A, Ramirez M, Barraza A, Orozco Mdel C, Cevallos MA, Lara M, Hernandez G, Iturriaga G: Improvement of drought tolerance and grain yield in common bean by overexpressing trehalose- 6 -phosphate synthase in rhizobia. Mol Plant Microbe Interact 2008, 21:958-966.
90. Blazquez MA, Lagunas R, Gancedo C, Gancedo JM: Trehalose-6-Phosphate, a new regulator of yeast glycolysis that inhibits hexokinases. Febs Letters 1993, 329:51-54

91. Muller J, Boller T, Wiemken A: Trehalose and trehalase in plants: recent developments. Plant Science 1995, 112:1-9.

92. Pardy RL, Spargo B, Crowe JH: Release of trehalose by symbiotic algae. Symbiosis 1989, 7:149-158.

93. Nelsen MP, Gargas A: Dissociation and horizontal transmission of codispersing lichen symbionts in the genus Lepraria (Lecanorales: Stereocaulaceae). New Phytol 2008, 177:264-275.

94. Piercey-Normore MD, DePriest PT: Algal switching among lichen symbioses. American Journal of Botany 2001, 88:1490-1498.

95. Piercey-Normore MD: The lichen-forming ascomycete Evernia mesomorpha associates with multiple genotypes of Trebouxia jamesii. New Phytol 2006, 169:331-344.

96. Mats Wedin HDGG: Saprotrophy and lichenization as options for the same fungal species on different substrata: environmental plasticity and fungal lifestyles in the Stictis-Conotrema complex. New Phytol 2004, 164:7.

97. Luo R, Liu B, Xie Y, Li Z, Huang W, Yuan J, He G, Chen Y, Pan Q, Liu Y: SOAPdenovo2: an empirically improved memory-efficient short-read de novo assembler. Gigascience 2012, 1:1-6.

98. Stanke M, Morgenstern B: AUGUSTUS: a web server for gene prediction in eukaryotes that allows user-defined constraints. Nucleic Acids Res 2005, 33:W465-W467.

99. Parra G, Blanco E, Guigó R: Geneid in drosophila. Genome research 2000, 10:511-515

100. Ter-Hovhannisyan V, Lomsadze A, Chernoff YO, Borodovsky M: Gene prediction in novel fungal genomes using an ab initio algorithm with unsupervised training. Genome research 2008, 18:1979-1990.

101. Haas BJ, Salzberg SL, Zhu W, Pertea M, Allen JE, Orvis J, White O, Buell CR, Wortman JR: Automated eukaryotic gene structure annotation using EVidenceModeler and the program to assemble spliced alignments. Genome Biol 2008, 9:R7.

102. Ashburner M, Ball CA, Blake JA, Botstein D, Butler H, Cherry JM, Davis AP, Dolinski K, Dwight SS, Eppig JT, et al: Gene ontology: tool for the unification of biology. Nat Genet 2000, 25:25-29.

103. Sonnhammer ELL, Koonin EV: Orthology, paralogy and proposed classification for paralog subtypes. Trends Genet 2002, 18:619-620

104. Ruepp A, Zollner A, Maier D, Albermann K, Hani J, Mokrejs M, Tetko I, Guldener U, Mannhaupt G, Munsterkotter M, Mewes HW: The FunCat, a functional annotation scheme for systematic classification of proteins from whole genomes. Nucleic Acids Res 2004, 32:5539-5545.

105. Kanehisa M, Goto S, Kawashima S, Okuno Y, Hattori M: The KEGG resource for deciphering the genome. Nucleic Acids Res 2004, 32:D277-D280.

106. Zdobnov EM, Apweiler R: InterProScan-an integration platform for the signature-recognition methods in InterPro. Bioinformatics 2001, 17:847-848.

107. Griffiths-Jones S, Moxon S, Marshall M, Khanna A, Eddy SR, Bateman A: Rfam: annotating non-coding RNAs in complete genomes. Nucleic Acids Res 2005, 33:D121-D124.

108. Lowe TM, Eddy SR: tRNAscan-SE: A program for improved detection of transfer RNA genes in genomic sequence. Nucleic Acids Res 1997, 25:955-964.

109. Karro JE, Yan Y, Zheng D, Zhang Z, Carriero N, Cayting P, Harrison P, Gerstein M: Pseudogene. org: a comprehensive database and comparison platform for pseudogene annotation. Nucleic Acids Res 2007, 35:D55-D60.

110. Lagesen $K$, Hallin P, Rødland EA, Stærfeldt H-H, Rognes T, Ussery DW: RNAmmer: consistent and rapid annotation of ribosomal RNA genes. Nucleic Acids Res 2007, 35:3100-3108.

111. Thompson JD, Higgins DG, Gibson TJ: Clustal-W - Improving the sensitivity of progressive multiple sequence alignment through sequence weighting, position-specific gap penalties and weight matrix choice. Nucleic Acids Res 1994, 22:4673-4680.

112. Baxevanis AD: Current protocols in bioinformatics. In Book Current protocols in bioinformatics (Editor ed.^eds.). City: Wiley; 2003.

113. Sanderson MJ: r8s: inferring absolute rates of molecular evolution and divergence times in the absence of a molecular clock. Bioinformatics 2003, 19:301-302.

114. Padovan ACB, Sanson GFO, Brunstein A, Briones MRS: Fungi evolution revisited: application of the penalized likelihood method to a bayesian fungal phylogeny provides a new perspective on phylogenetic 
relationships and divergence dates of ascomycota groups. $J \mathrm{Mol}$ Evol 2005, 60:726-735.

115. Li H, Coghlan A, Ruan J, Coin LJ, Heriche JK, Osmotherly L, Li RQ, Liu T, Zhang Z, Bolund L, et al: TreeFam: a curated database of phylogenetic trees of animal gene families. Nucleic Acids Res 2006, 34:D572-D580.

116. Enright AJ, Van Dongen S, Ouzounis CA: An efficient algorithm for large-scale detection of protein families. Nucleic Acids Res 2002, 30:1575-1584.

117. Librado P, Vieira FG, Rozas J: BadiRate: estimating family turnover rates by likelihood-based methods. Bioinformatics 2012, 28:279-281.

118. Galagan JE, Calvo SE, Cuomo C, Ma LJ, Wortman JR, Batzoglou S, Lee SI, Basturkmen M, Spevak CC, Clutterbuck J, et al: Sequencing of Aspergillus nidulans and comparative analysis with A-fumigatus and A-oryzae. Nature 2005, 438:1105-1115.

119. Glass NL, Kaneko I: Fatal attraction: Nonself recognition and heterokaryon incompatibility in filamentous fungi. Eukaryot Cell 2003, 2:1-8.

120. Dementhon K, Saupe SJ, Clave C: Characterization of IDI-4, a bZIP transcription factor inducing autophagy and cell death in the fungus Podospora anserina. Mol Microbiol 2004, 53:1625-1640.

121. Saupe S, Descamps C, Turcq B, Begueret J: Inactivation of the podosporaanserina vegetative incompatibility locus Het- $C$, whose product resembles a glycolipid transfer protein, drastically impairs ascospore production. P Natl Acad Sci USA 1994, 91:5927-5931.

122. Anand S, Prasad MVR, Yadav G, Kumar N, Shehara J, Ansari MZ, Mohanty D: SBSPKS: structure based sequence analysis of polyketide synthases. Nucleic Acids Res 2010, 38:W487-W496.

123. Vandesompele J, De Preter K, Pattyn F, Poppe B, Van Roy N, De Paepe A, Speleman F: Accurate normalization of real-time quantitative RT-PCR data by geometric averaging of multiple internal control genes. Genome Biol 2002, 3:research0034.

doi:10.1186/1471-2164-15-34

Cite this article as: Wang et al:: Genome characteristics reveal the impact of lichenization on lichen-forming fungus Endocarpon pusillum Hedwig (Verrucariales, Ascomycota). BMC Genomics 2014 15:34.

\section{Submit your next manuscript to BioMed Central and take full advantage of:}

- Convenient online submission

- Thorough peer review

- No space constraints or color figure charges

- Immediate publication on acceptance

- Inclusion in PubMed, CAS, Scopus and Google Scholar

- Research which is freely available for redistribution 